\title{
KOMATIITIC AND THOLEIITIC METAVOLCANICS OF THE SIIVIKKOVAARA AREA IN THE ARCHEAN KUHMO GREENSTONE BELT, EASTERN FINLAND
}

\author{
EERO HANSKI
}

\begin{abstract}
HANSKI, EERO 1980: Komatiitic and tholeitic metavolcanics of the Siivikkovaara area in the Archean Kuhmo greenstone belt, eastern Finland. Bull. Geol. Soc. Finland 52, 67-100.

Komatiitic metavolcanics are abundant and well-preserved in the Siivikkovaara area, which lies in the middle part of the Archean IKuhmo greenstone belt. Together with the underlying tholeites, these form the Kellojärvi Group, which is divided into two formations, those of Pahakangas and Siivikkovaara.

The Pahakangas Formation consists of pillowed and massive metalavas and intercalated banded iron formations. The metalavas are chemically typical Archean low-potassium tholeiites. The overlying Siivikkovaara Formation has three subunits, the Siivikko, Mäkinen and Raivio Members. The metavolcanics of the Siivikko Member, which are mainly peridotitic komatiites ( $\mathrm{MgO} \geq 18 \%$ ), have many structures typical of extrusive rocks, including breccias, pillows, spinifex textures and polygonal jointing. The microspinifex-textured rocks richest in magnesium contain about $20 \% \mathrm{MgO}$. The Mäkinen Member consists of basaltic and pyroxenitic komatiites (MgO $<18 \%$ ), which occur in the form of variolitic pillow lavas. The Raivio Member is composed of ultramafic to mafic metatuffs.

The spinifex textures in the Siivikkovaara area were originally formed by clinopyroxene. Zones $A_{1}, A_{2}, B_{1}$ and $B_{2}$ can be distinguished in the spinifex-textured lava flows, and $\mathrm{A}_{2}$ has further subunits dominated by dendritic, platy or acicular hornblende pseudomorphs after clinopyroxene. The liquid composition of the spinifextextured flows is deduced to be in the range of pyroxenitic komatiite. These flows are differentiated mainly by olivine and minor pyroxene and chromite precipitation. Albite in the spinifex-textured rocks is formed through sodium metasomatism caused by sea-water.

There are many indicators to support the notion of a deep-sea origin for the lavas of the Kellojärvi Group. Despite the relatively low $\mathrm{MgO}$ content of the komatiites in the Siivikkovaara Formation, two nickel-copper occurences have been found in the formation.
\end{abstract}

University of Oulu, Department of Geology, Kasarmintie 15, SF-90100 Oulu 10, Finland.

\section{Introduction}

Since komatiites were discovered and defined in Barberton Mountain Land, South Africa, by Viljoen \& Viljoen (1969a) these rocks of considerable importance for petrology and ore prospecting have been seen to occupy an essential role in the lithology of Archean greenstone belts. Further finds of komatiites have been made in Rhodesia (Bickle et al., 1975), Australia (Nesbitt, 1971) Canada (Pyke et al., 1973), India (Dessai \& Deshpande, 1979) and Greenland (McGregor \& Mason, 1977), and they have also been observ- 
ed to exist in the Baltic Shield, both in the Soviet Union (Suslova, 1976) and in Finland (Mutanen, 1976).

The extrusive character of ultramafic amphibole- and amphibole-chlorite rocks occurring in Finnish Lapland was emphasized as early as in the 1930's by Mikkola (1941), who regarded them as picritic volcanic rocks. The same name was later used by Meriläinen (1976), while Paakkola (1971) called them ultrabasic lava-born rocks and Mutanen (1976) has demonstrated their chemical similarity to komatiites. Komatiitic ultramafites have also been recognized in Lapland by $\mathrm{Pa}-$ punen et al. (1977) and Isomaa (1978).

In addition to the 'komatiite province' of Central Lapland Mutanen (1976) separated two other provinces, those of eastern Kainuu and Tipasjärvi. The two latter will be known here by the name of the 'Kuhmo greenstone belt' (Fig. 1). On the basis of geochemical studies a group of French scientists divided the metavolcanics of the Kuhmo greenstone belt into two lithostratigraphical units, the older of which contains rocks of komatiite and tholeiite series, while the younger one consists of rocks of the calc-alkali series (Blais et al., 1978). Other authors to distinguish komatiites in this area are Luukkonen (1978) at Moisiovaara and Taipale (1979) at Tipasjärvi.

Komatiitic metavolcanics are to be encountered almost uninterruptedly throughout the length of the Kuhmo greenstone belt. They are especially abundant and well-preserved together with tholeiitic metavolcanics in the Siivikkovaara area (Fig. 1), and it is on this occurrence that the present paper will concentrate. This area also features spinifextextured lava flows, which have not been described before in Finland, the only detailed study of such rocks so far being one concerning a microspinifex-tectured rock from $\mathrm{Ti}$ pasjärvi (Blais et al., in prep.).

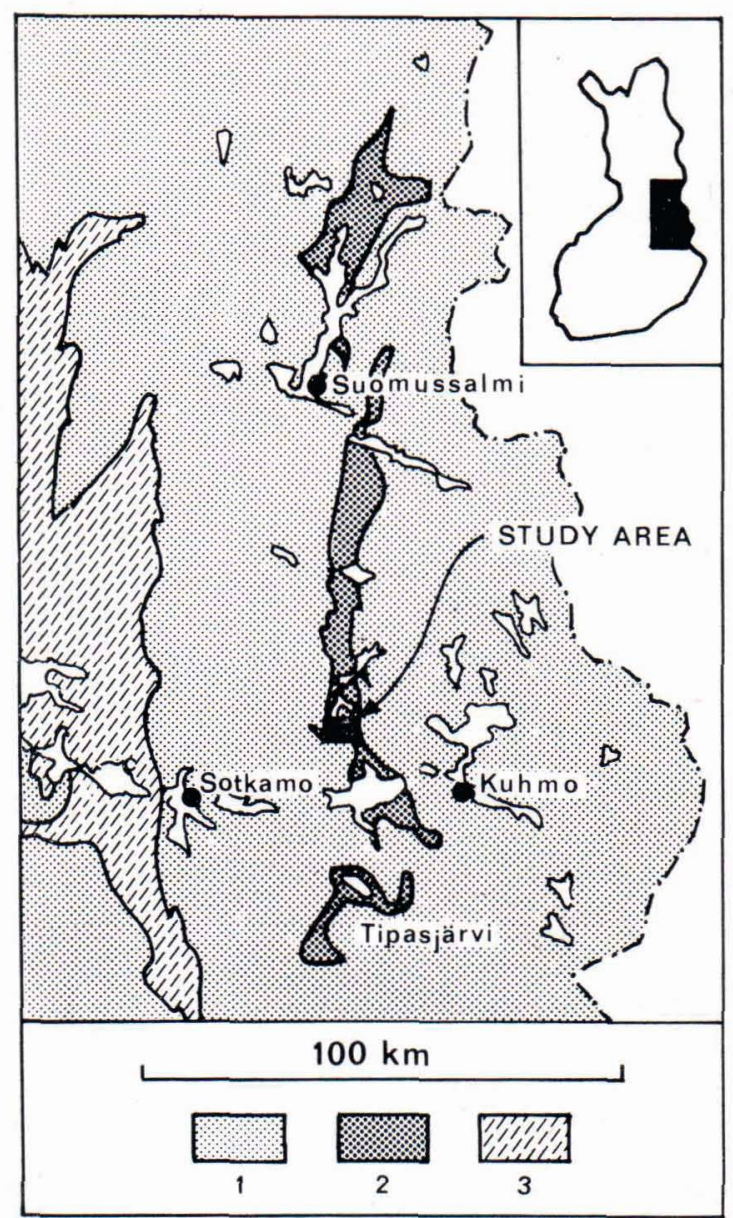

Fig. 1. Location map of the study area. Key: 1, Archean granitoids; 2, Kuhmo greenstone belt; 3 , Proterozoic schists.

The nomenclature and classification of the komatiites as laid down in the scheme of Arndt et al. (1977) will be followed, except for the boundary between pyroxenitic and peridotitic komatiites, which is set at an $\mathrm{MgO}$ value of $18 \%$.

\section{General geology}

The Kuhmo greenstone belt in Eastern Finland forms a typical Archean greenstone belt surrounded by a vast amount of granitoids (Wilkman, 1924; Matisto, 1954; Gaál et 


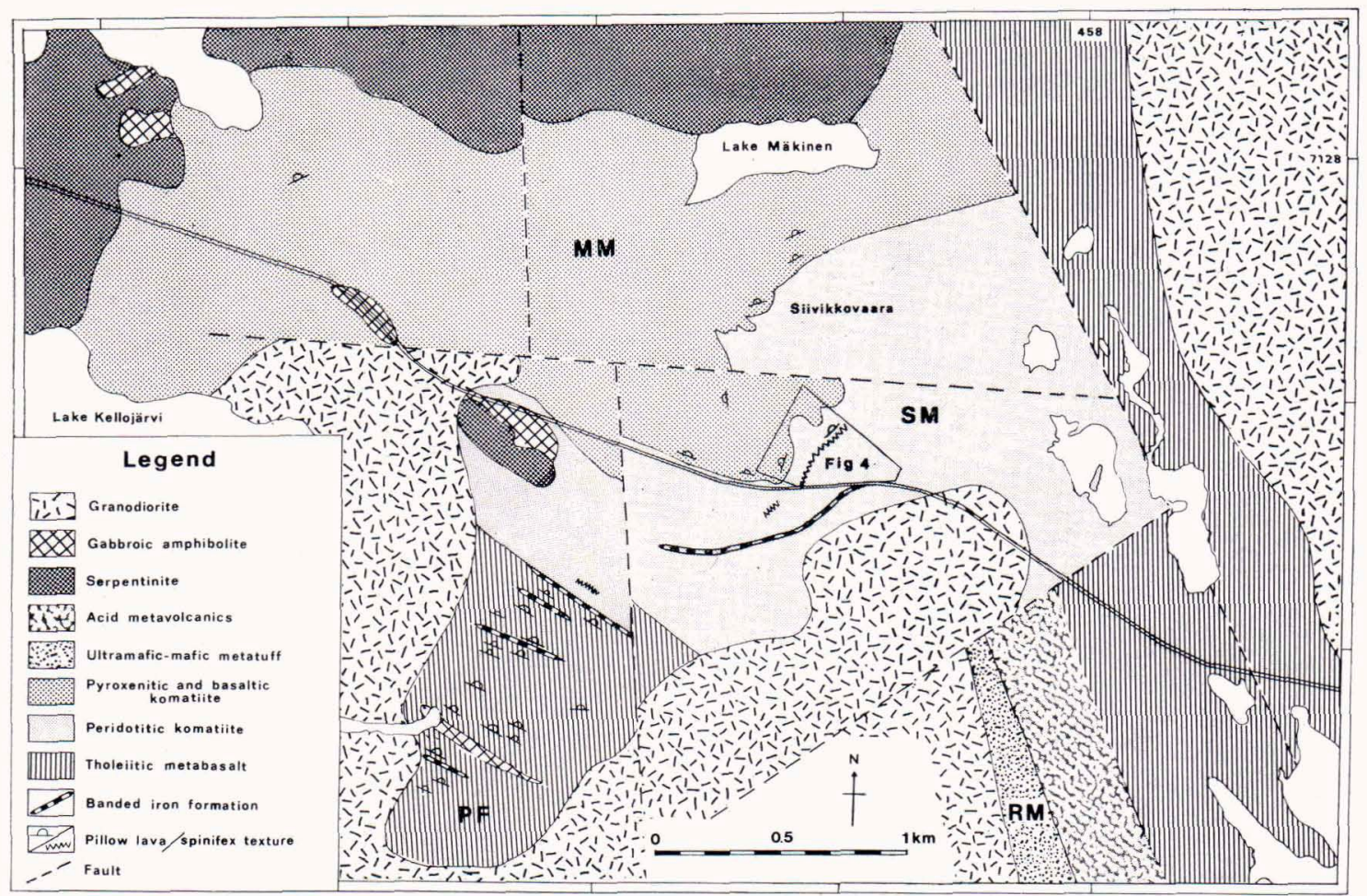

Fig. 2. Geological map of the Siivikkovaara area. Key: PF = Pahakangas Formation; SM $=$ Siivikko Member; $M M M=$ Mäkinen Member; $R M=$ Raivio Member.

al., 1978). It runs from south to north in a narrow belt some $200 \mathrm{~km}$ in length, and consists of three separate parts, the southern (Tipasjärvi), the middle (between Kuhmo and Suomussalmi) and the northern (Suomussalmi) area (Fig. 1). The Siivikkovaara area (Fig. 2) is situated in the middle part of this belt.

The area has been mapped earlier by Wilkman (1924), on the scale 1:400000, and by Hyppönen (1976), on the scale 1: 100000.

The volcanic rocks of the Siivikkovaara area belong to the Kellojärvi Group, which represent the lowest stratigraphical rock association in the southern part of the Kuhmo greenstone belt. The underlying substrate has not been encountered. The lowermost metavolcanics are cut by granodiorite (Fig. 2). The Ontojärvi Group, which overlies the Kellojärvi Group, includes acid metavolcanics, quartzites, tholeiitic metabasalts, peridotitic komatiites and mica schists. The Kellojärvi metavolcanics extend back more than 2759 Ma (Geological Survey of Finland, Ann. Rep. 1975), which is the age of the overlying acid metavolcanics of the Ontojärvi Group.

The Kellojärvi Group may be divided into two formations, the lower is Pahakangas Formation and the upper is Siivikkovaara Formation. The Pahakangas Formation, some $1.2 \mathrm{~km}$ in thickness, is characterized by basaltic pillow lavas alternating with iron formations. Altogether 10 iron formations have been found, varying in thickness from $0.1-$ $3 \mathrm{~m}$. The uppermost of these is located between the Pahakangas and Siivikkovaara Formations, and represents the sulphide facies, while the others are oxide facies formations. These rocks have been described by Papunen (1960), Niiniskorpi (1975), Lehto \& 
Niiniskorpi (1977) and Tuokko (1979), and require no further comments here.

The Siivikkovaara formation is divisible into three members: Siivikko, Mäkinen and Raivio. The lowest subunit, the Siivikko Member, is about $0.5 \mathrm{~km}$ thick and is composed largely of peridotitic komatiites. A variety of structures typical of extrusive rocks may be seen in this unit, including spinifex textures, pillows and breccias, and it also contains one narrow iron formation, representing an oxide facies, located approx. $300 \mathrm{~m}$ from the lover edge of the member and underlain by a narrow mafic — felsic metatuff.

The Mäkinen Member, the middle subunit, is composed of pyroxenitic and basaltic komatiites, which occur chiefly as pillow lavas. Variolitic textures are common in these pillows. This unit varies in thickness from half a kilometre to just under a kilometre.

The uppermost subunit in the Siivikkovaara Formation is the Raivio Member, composed of an ultramafic - mafic metatuff several hundred metres in thickness. The metatuffs have not been analysed, but their mineralogy shows that they are komatiitic in composition, and are therefore included in the same formation with the Siivikko and Mäkinen Members.

The Mäkinen and Raivio Members are separated by the large serpentinite massif of Näätäniemi. Judging from its folded magmatic layering this serpentinite must be an intrusive rock which emplaced between the volcanics at an early stage.

It is typical of the structure of the Siivikkovaara area that both the Pahakangas Formation and the two lowermost subunits of the Siivikkovaara Formation, the Siivikko and Mäkinen Members, run roughly at right angles to the $\mathrm{N}-\mathrm{S}$ trend of the greenstone belt as a whole. Once having bent around the Näätäniemi serpentinite massif, however, the metavolcanics assume a $\mathrm{N}-\mathrm{S}$ orientation to the north. The dip of the bedding is generally almost vertical, varying between $70^{\circ}$ and $90^{\circ}$. Deformation may be seen in the metalavas of the Pahakangas Formation largely in the form of extensive fracturing, as there is normally no schistosity to be observed. The general low grade of deformation may be seen in the well-preserved microtextures of the pillow lavas. Schistosity is more pronounced in the metalavas of the Siivikkovaara Formation, and a clear lineation due to the growth of the long hornblende prisms may frequently be observed in the basaltic and pyroxenitic komatiites in particular. The strike of the schistosity generally varies between $130^{\circ}$ and $150^{\circ}$, with a dip of $75^{\circ}-85^{\circ}$ to the southwest. The lineation plunges $67^{\circ}-85^{\circ}$ in direction $260^{\circ}$. Similar schistosity and lineation values are also predominant in the granodiorites which cut the metavolcanics of this area. Some metavolcanics present evidence of a more recent vertical crenulation cleavage in an $\mathrm{E}-\mathrm{W}$ direction.

The rocks of this area have undergone regional metamorphism in which the original dark minerals have almost without exception been altered. Judging from the hornblende - oligoclase or hornblende - andesine assemblage in the mafic rocks and the actinolite - chlorite or tremolite - chlorite assemblage in the ultramafic rocks, metamorphism must have taken place under conditions of a lower amphibolite facies.

\section{Petrography}

\section{The Pahakangas Formation}

The volcanic rocks of the Pahakangas Formation are interlayered massive and pillowed metalavas. The units of massive metavolcanics vary in thickness from 10 to $200 \mathrm{~m}$, and 


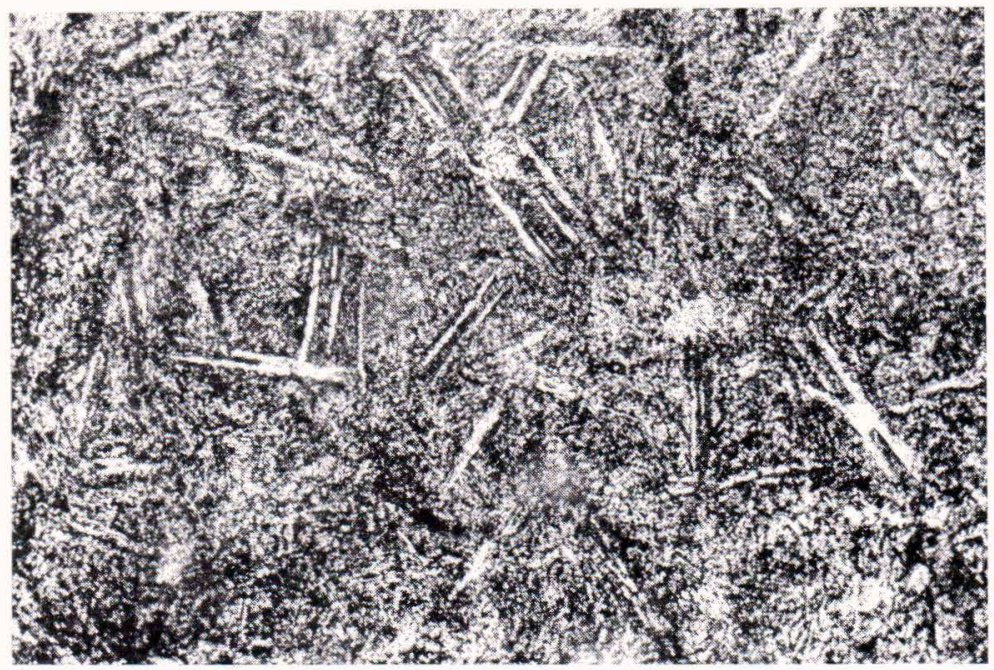

Fig. 3. Photomicrograph of skeletal plagioclase microlites in a fine-grained hornblende matrix. Plane polarized light; photo length $2 \mathrm{~mm}$.

are non-oriented dark green rocks of a grain size slightly larger than that of the pillow lavas, although still generally under $1 \mathrm{~mm}$. The major minerals are hornblende and plagioclase $\left(\mathrm{An}_{\sim 30}\right)$ and the accessories are clinozoisite, sphene, opaque, quartz, apatite and biotite. The original texture has generally been destroyed and e.g. plagioclase is seldom found in the form of laths, for it has usually re-crystallized to granoblastic mosaic, commonly occurring as zoned grains with the edges richer in An than the centres.

Non-deformed and well-preserved pillow lavas may be seen in many of the horizons, the pillows generally being of size $0.2-1.5 \mathrm{~m}$. Because of the steep dip of the bedding, these pillows are largely to be seen in cross-section, enabling bun, balloon and mattress types to be distinguished. The upper parts of some pillows contain quartz-filled parallel lenses, which may be used together with the pillow forms to determine the orientation of the depositional substrate. These lenses were originally horizontal gas cavities (cf. MacDonald, 1967).

Mineralogically the pillow lavas resemble massive metavolcanics, consisting mainly of hornblende and plagioclase $\left(\mathrm{An}_{30-35}\right)$. The intervening masses between the pillows are $1 \mathrm{~cm}$ broad on the average and are composed for the most part of clinozoisite and to a lesser extent of plagioclase and hornblende. The pillows have about $0.5 \mathrm{~cm}$ thick hornblende rim of a very fine grain size. Immediately inside of the rim plagioclase occurs as narrow, skeletal grains $\leq 0.4 \mathrm{~mm}$ in length. The ratio of length to width in these grains may be as much as 10: 1, and they are frequently hollow at the ends, which becomes visible in the longitudinal section as a swallow-tail (Fig. 3) and in the cross-section as a hollow square or rectangle (belt-buckle plagioclase). These quench plagioclases have sometimes re-crystallized to a granoblastic mosaic, but the original forms are still clearly visible. In addition to these skeletal microlites, plagioclase occurs as microphenocrysts, which have usually been partially altered to clinozoisite. There are also aggregates of hornblende which may represent microphenocrysts of some mafic mineral.

The plagioclase microlites become gradually more coarse-grained towards the centre of the pillow, and the rock takes on a blastointergranular or blastosubophitic texture. The skeletal character of the plagioclase crystals 


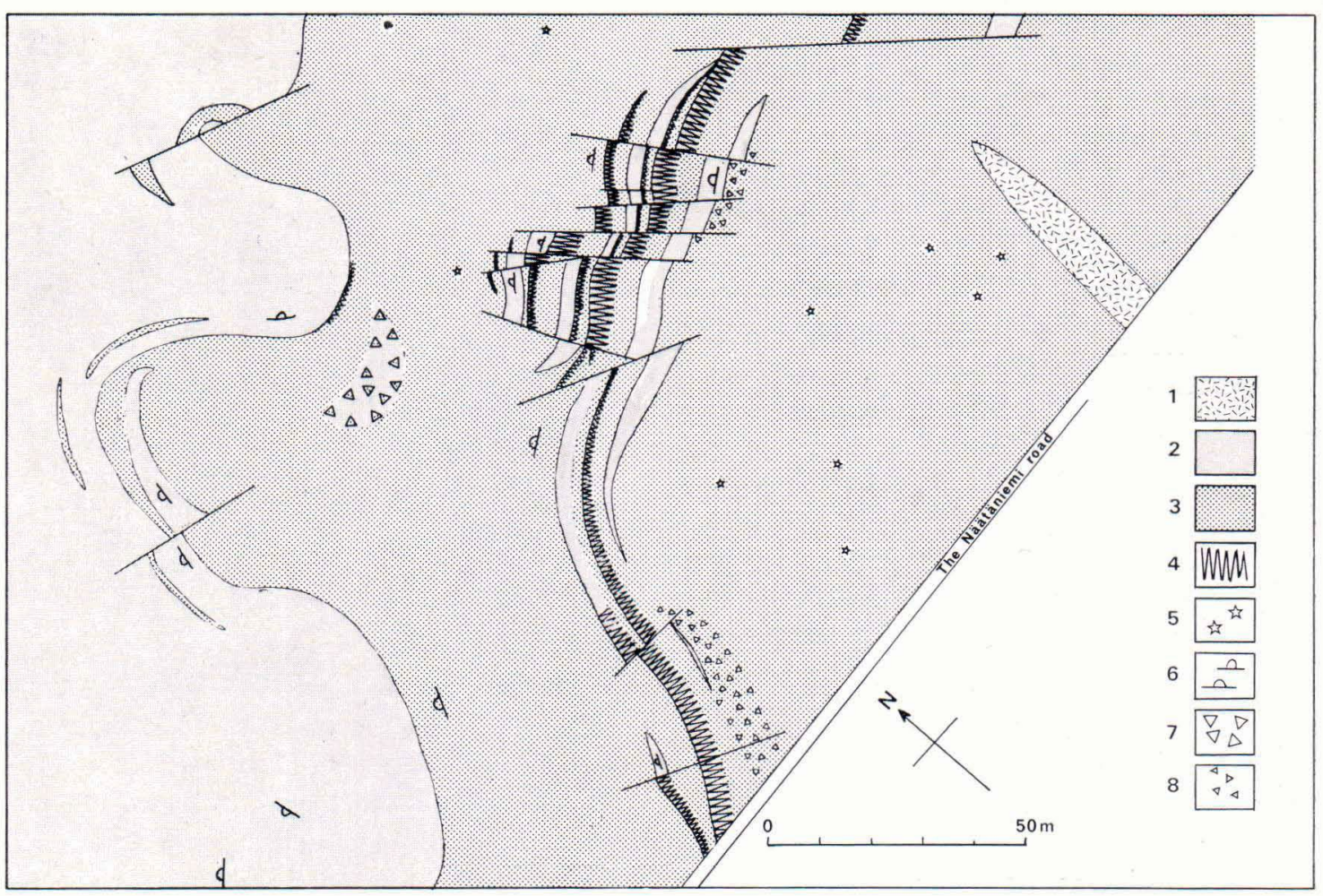

Fig. 4. Detailed map of the north side of the road to Näätäniemi showing volcanogenic structures and the contact between the Siivikko and Mäkinen members. Key: 1, plagioclase porphyry; 2, pyroxenitic and basaltic komatiite; 3, peridotitic komatiite; 4, spinifex texture; 5, microspinifex texture; 6, pillow lava; 7, coarse volcanic breccia (see fig. 22); 8, autoclastic volcanic breccia (see fig. 21).

may nevertheless be retained right to the centre of the pillow, especially in the smaller pillows.

In cases where there is little plagioclase present the hornblende may form narrow prism-like shapes, which may perhaps represent earlier clinopyroxene prisms.

In the upper part of the Pahakangas Formation the pillow lavas contain large plagioclase phenocrysts as much as $2.5 \mathrm{~cm}$ in size. These have been partly or wholly altered to granoblastic clinozoisite - plagioclase quartz mass, but their forms are still wellpreserved. Thus the pillow lavas may be said to contain three generations of plagioclase, a situation similar to that noted by Baragar et al. (1977) in tholeiites from the Mid-Atlantic Ridge, according to whom megaphenocrysts record a crystallization history that began at great depth. As the microphenocrysts crystallized out, the magma rose to the surface and skeletal microlites formed during quenching on the sea floor.

\section{The Siivikkovaara Formation}

\section{Siivikko Me mber}

The lowest member of the Siivikkovaara Formation, the Siivikko Member, is composed chiefly of peridotitic komatiites, with a few interlayers of pyroxenitic komatiite. These rocks now contain varying amounts of lightcoloured amphibole, hornblende, chlorite and plagioclase. The chlorite would seem from both its optical and $\mathrm{x}$-ray properties to be 
clinochlore. The light-coloured amphibole is usually light green actinolite, except in the rocks richest in $\mathrm{MgO}$, in which it is colourless tremolite. Concluding from the pseudomorphs and the chemistry of the rock the principal original minerals seem to have been olivine, clinopyroxene and plagioclase, the first two of which are no longer to be encountered anywhere. In spite of the almost complete alteration of the original mineralogy, the volcanogenic structures and textures are often excellently preserved. This is true, for example, in the relatively well-exposed area to the north of the Näätäniemi road (Fig. 4).

\section{Spinifex-textured metalavas}

Seven localities in the Kuhmo greenstone belt are known at present where spinifextextured rocks occur. In the Siivikkovaara area, as in most of the other occurrences, the spinifex texture was formed originally by clinopyroxene. Owing to the low $\mathrm{MgO}$ content, the spinifex zone is predominantly mafic rock in which the principal original minerals were clinopyroxene, plagioclase and to a lesser extent olivine, whereas the cumulate zone lying below this is entirely ultramafic, having originally been formed of clinopyroxene and olivine. The spinifex and cumulate zones are easily distinguishable one from another by virtue of their differences in mineralogy and texture (Fig. 5). The lava beds vary in thickness from 2 to $17.5 \mathrm{~m}$. The same lava bed can be followed for about $150 \mathrm{~m}$ in places, but because of the conditions of exposure their lateral extensions cannot be measured exactly.

Donaldson (1974) classifies spinifex textures into four types according to the habit of their olivine crystals: (1) plate, (2) randomly oriented, (3) porphyritic, and (4) branching. The first two of these types are encountered in the rocks of the Siivikkovaara area, but with the difference that here it is a question of clinopyroxene rather than olivine crystals. In the plate spinifex type bundles of parallel clinopyroxene plates are cross-cut randomly by other sets of plates, or form coarse fans perpendicular to the bedding, whereas the randomly oriented type is composed of acicular clinopyroxene.

The lava beds may be divided into zones A and B with subunits (Fig. 6) in the same manner as the olivine spinifex-textured flows (see Pyke et al., 1973; Barnes et al., 1974). Many authors have noted that spinifex crystals become more coarse-grained towards the base of the spinifex zone (e.g. Lajoie \& Gelinas, 1978). In the Siivikkovaara area, however, the plate spinifex type is found in the upper part of zone $A_{2}$, while the more finegrained randomly oriented type is dominant in the lower part, as seen in the idealized

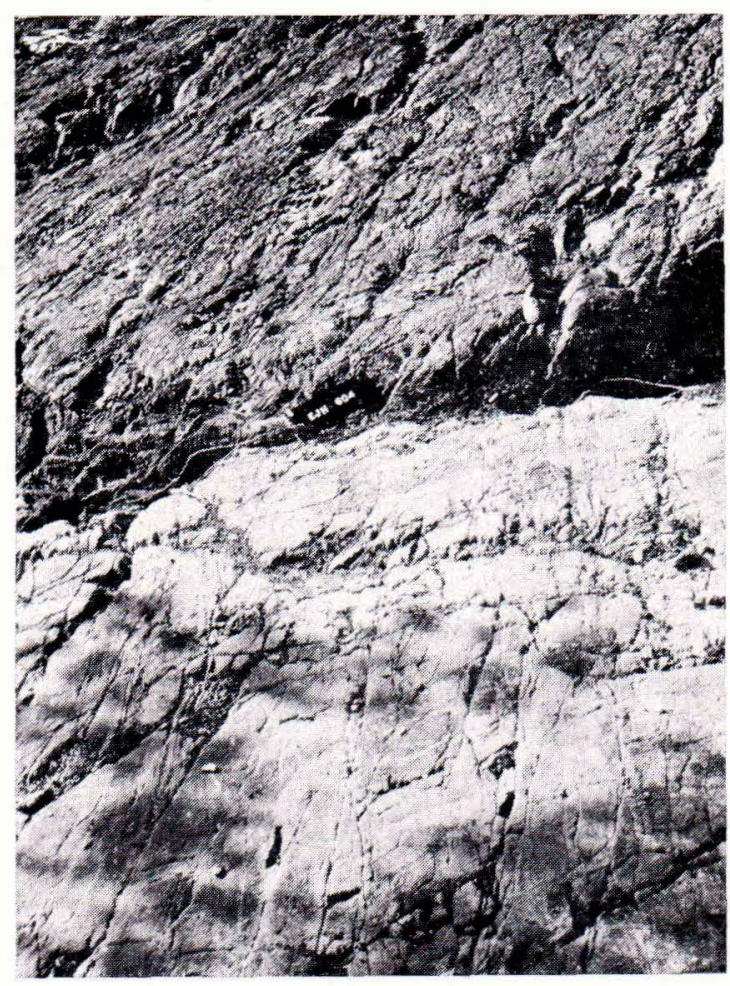

Fig. 5. General view of a spinifex-textured lava flow. The cross-section is about $5 \mathrm{~m}$ long. 


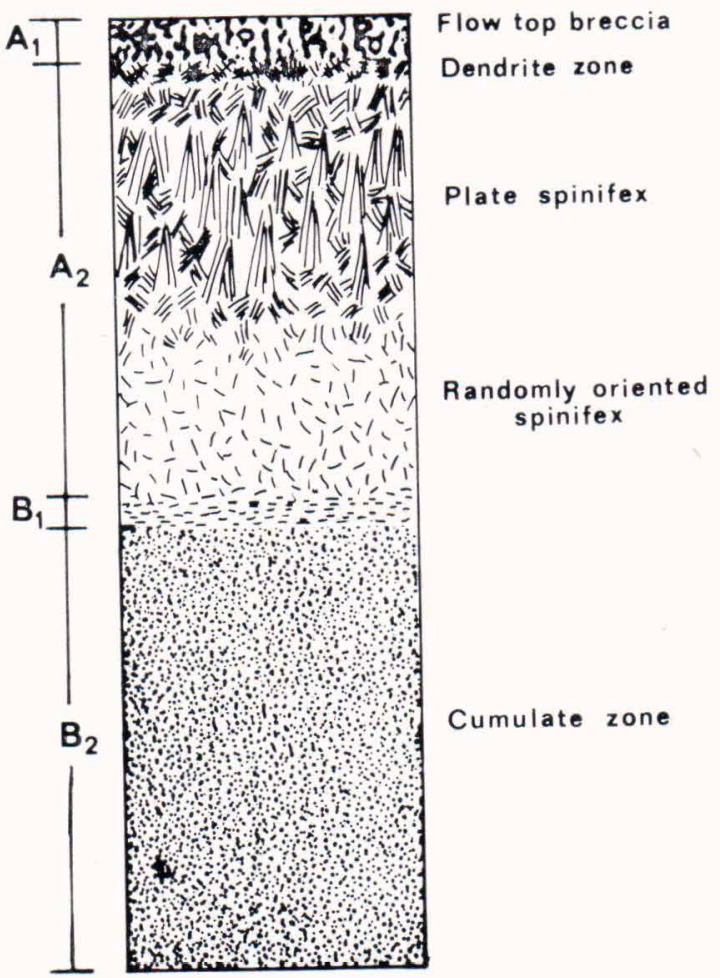

Fig. 6. Idealized cross-section of a spinifex-textured lava flow in the Siivikkovaara area.

cross-section in Fig. 6. This ordering has also been observed at other sites where the spinifex texture is formed by clinopyroxene (Arndt et al., 1977; Nisbet et al., 1977; Williams \& Furnell, 1979).

The flow top breccia, zone $A_{1}$ (Fig. 7), may vary in thickness from $0.2 \mathrm{~m}$ to $1.5 \mathrm{~m}$, and is distinguishable from the underlaying zone $\mathrm{A}_{2}$ as being a clearly lighter rock in colour with rounded or angular fragments. The breccia consists mainly of weakly pleochroic actinolite together with chlorite, which may itself sometimes reach the status of a major mineral. One accessory is ilmenite, which forms rugged needles as much as $6 \mathrm{~mm}$ in length. In places one finds the texture seen in Fig. 8, in which a rock composed of amphibole contains adjacent triangular or rectangular patches. This rock may have origi-

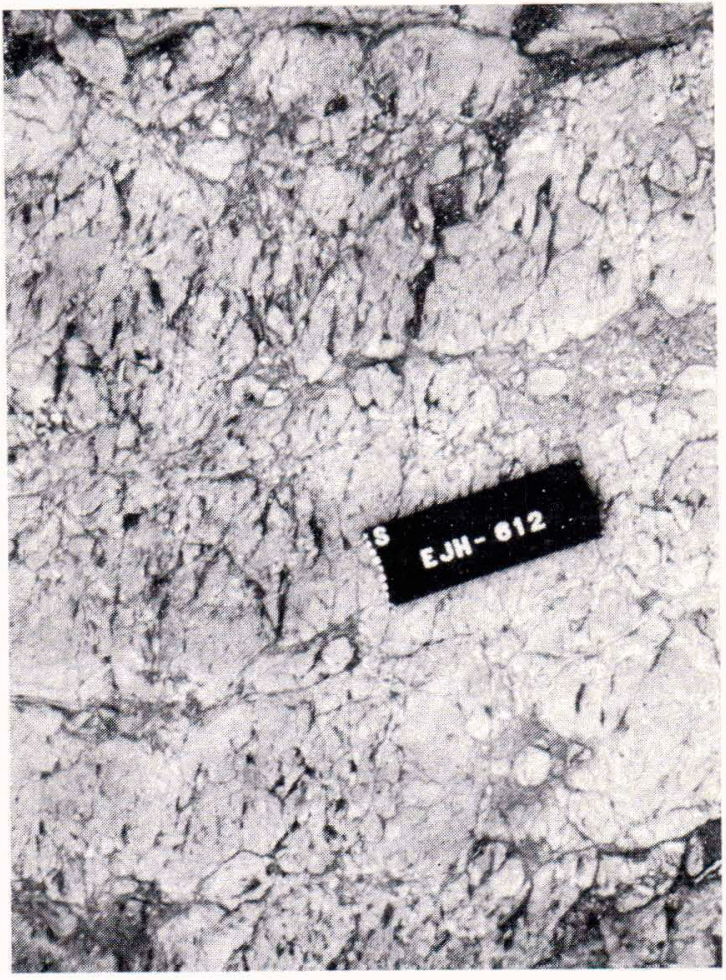

Fig. 7. Flow top breccia of a spinifex-textured lava flow. The length of the number plate is $16,5 \mathrm{~cm}$

nally consisted of fine clinopyroxene (or olivine) needles separated by glass (cf. Upadhyay, 1978, fig. le), as actinolite has a brownish tinge and possesses dendritic forms which may arise during devitrification (Rogers, 1970). The flow top breccia is also microscopically blastoporphyric, as it contains chlorite pseudomorphs of size $0.2-1 \mathrm{~mm}$ after olivine phenocrysts.

Zone $\mathrm{A}_{2}$ begins with a dendrite zone (Fig. 9) of thickness $0.2-1.5 \mathrm{~m}$ which is macroscopically dark green in colour and finegrained, thus standing out clearly from the underlying plate spinifex-textured rock. Dendrite zone is composed principally of hornblende and minor amounts of chlorite, plagioclase and devitrified glass. The hornblende, which occurs in the form of pseudomorphs after clinopyroxene, forms decorative den- 


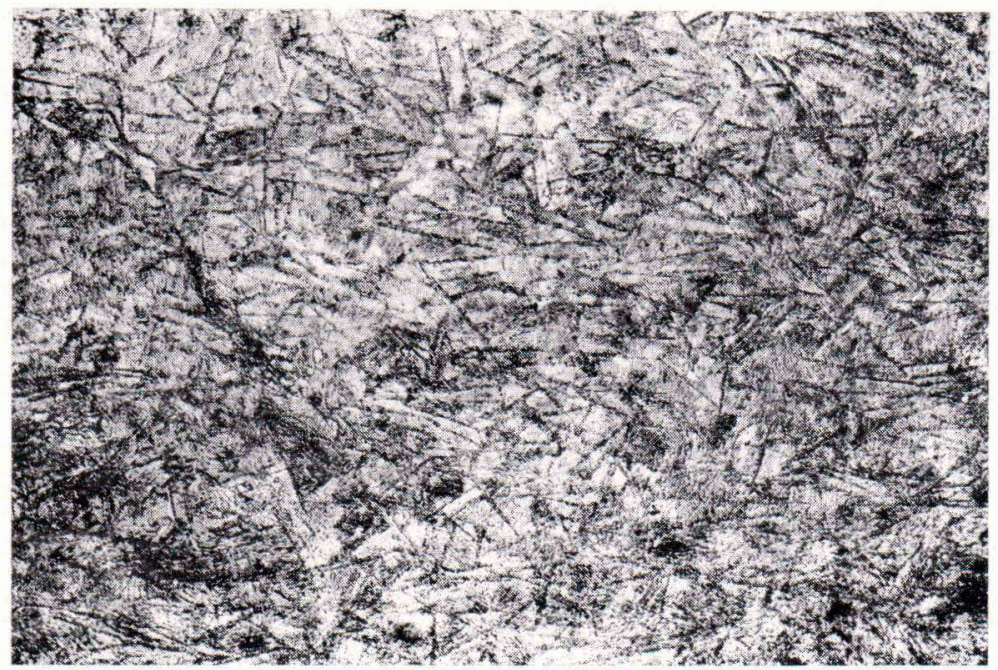

Fig. 8. Photomicrograph of texture in a top breccia of a spinifex-textured lava flow. The rock is composed of actinolite and minor chlorite. Plane polarized light; photo length $4 \mathrm{~mm}$.

drites of size $\leq 1.5 \mathrm{~mm}$ (Fig. 10), which in turn are composed of thin plates, $0.01 \mathrm{~mm}$ in thickness, oriented on the plane (010) and joined by couplings oriented along the $\mathrm{b}$ axis. The hornblende also forms bundles of narrow, plate-like grains $0.02-0.04 \mathrm{~mm}$ in thickness, some of which still retain in a clearly visible form the skeletal habit of the original clinopyroxene crystals (Fig. 11). The chlorite forms oval spots, which represent the original olivine grains. It is obvious that the dendrites of this dendrite zone do not result from devitrification as do those in the flow top breccia, since they are very much larger than the latter and stand out distinctly from the very fine-grained brown mass which fills the interstices and represents the original glass in this zone. In addition to this devitrified glass, the interstices between the hornblende pseudomorphs also contain a small amount of plagioclase.

The plate spinifex texture of zone $\mathrm{A}_{2}$ is brought about by hornblende pseudomorphs of platy clinopyroxene crystals which are well-developed in the directions of the a and c axes and at their narrowest in the direction of the $b$ axis. These parallel plates form cross-cutting, randomly oriented bundles of maximum length $5 \mathrm{~cm}$, or longer fans $(\leq 40$ $\mathrm{cm}$ ) oriented perpendicular to the bedding (Fig. 12). The individual grains are $0.2-0.3$

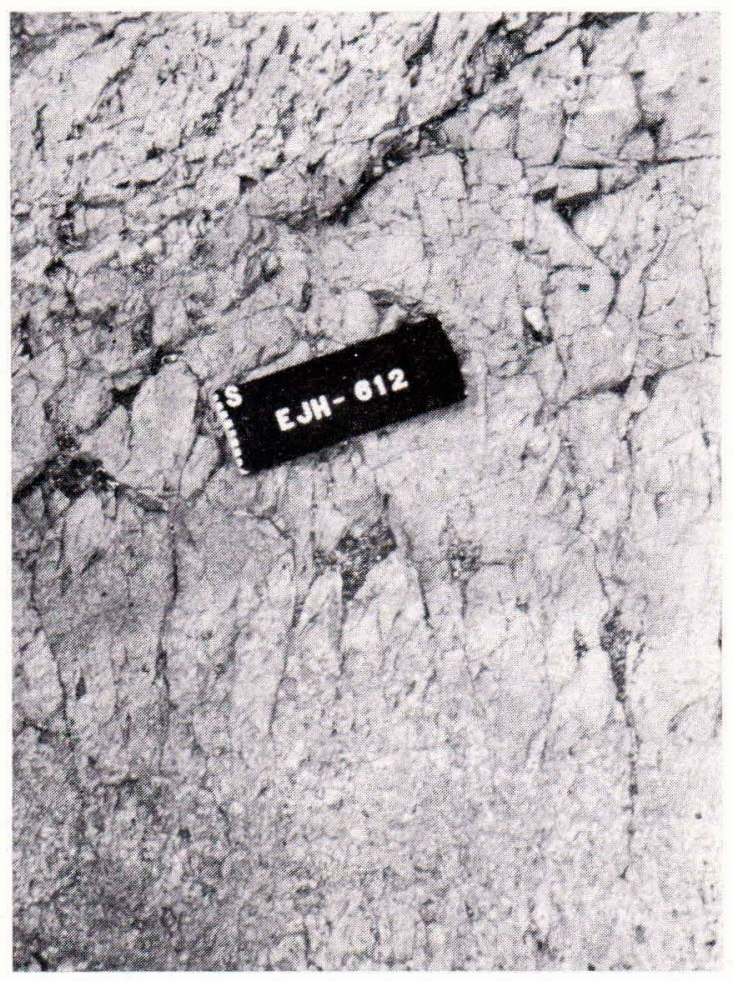

Fig. 9. Fine-grained dendrite zone between flow top breccia and plate spinifex-textured rock. The length of the number plate is $16,5 \mathrm{~cm}$. 


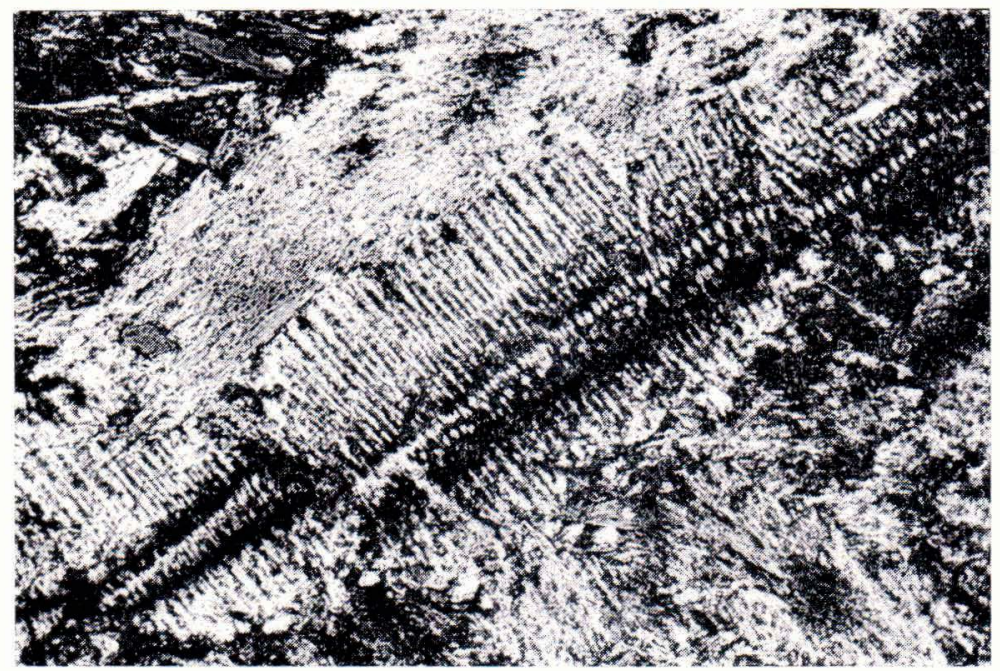

Fig. 10. Photomicrograph of a dendritic hornblende pseudomorph after clinopyroxene in the dendrite zone of a spinifextextured lava flow. Crossed polars; photo length $2 \mathrm{~mm}$.

$\mathrm{mm}$ broad (Fig. 13) and rarely exceed one centimetre in length, but when oriented en echelon the plates give the impression macroscopically of individual grains extending for as much as a number of decimetres. Large numbers of the hornblende plates are oriented optically parallelly. The interstices between these plates are filled by intergrowths of hornblende and plagioclase, which, where there is space, can easily form fan spherulites attached to the plates by their bases.

These spherulites are particularly well-de- veloped in the randomly oriented spinifex type, where open spaces remain between the hornblende pseudomorphs of clinopyroxene (Fig. 14). In this spinifex type clinopyroxene forms primarily long $(\leq 1 \mathrm{~cm})$ narrow $(\leq 0.3$ $\mathrm{mm}$ ) needles elongated in the direction of the c axis (Fig. 15). Like the platy pseudomorphs, these too now often possess a chlorite core surrounded by a hornblende rim, the chlorite apparently representing the original pigeonite core surrounded by augite. Clinopyroxene crystals of this kind, with a pronounced zona-
Fig. 11. Photomicrograph of small hornblende pseudomorphs after skeletal clinopyroxene in devitrified glass. The opaque mineral is ilmenite. Plane polarized light; photo length $1 \mathrm{~mm}$.

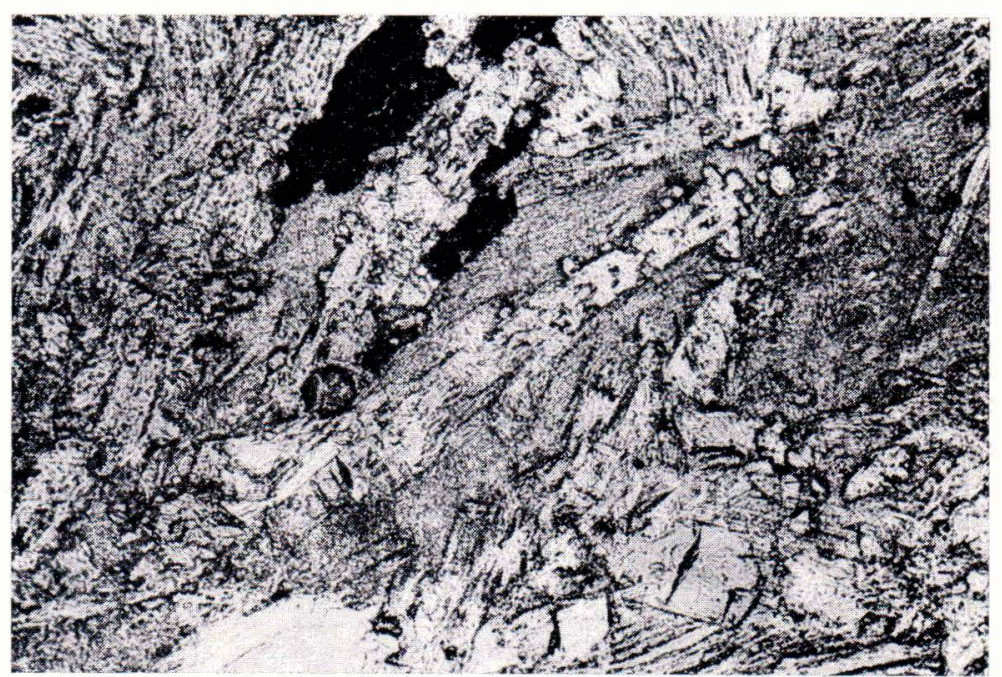




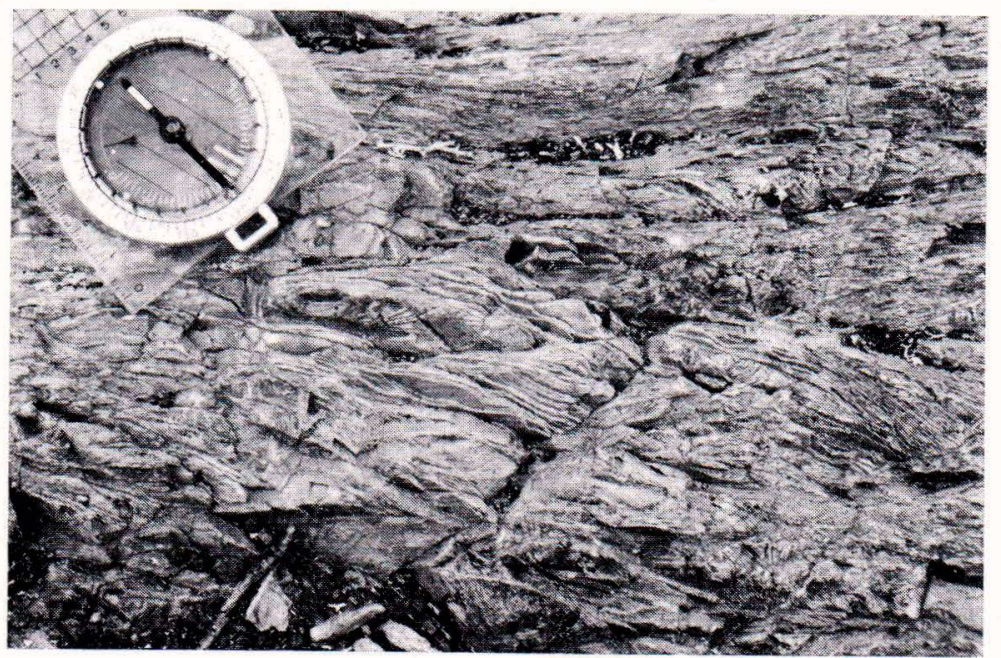

Fig. 13. Photomicrograph of parallel hornblende pseudomorphs of platy clinopyroxene crystals and interstitial intergrowths of hornblende (after clinopyroxene) and plagioclase. Plane polarized light; photo length $4 \mathrm{~mm}$.

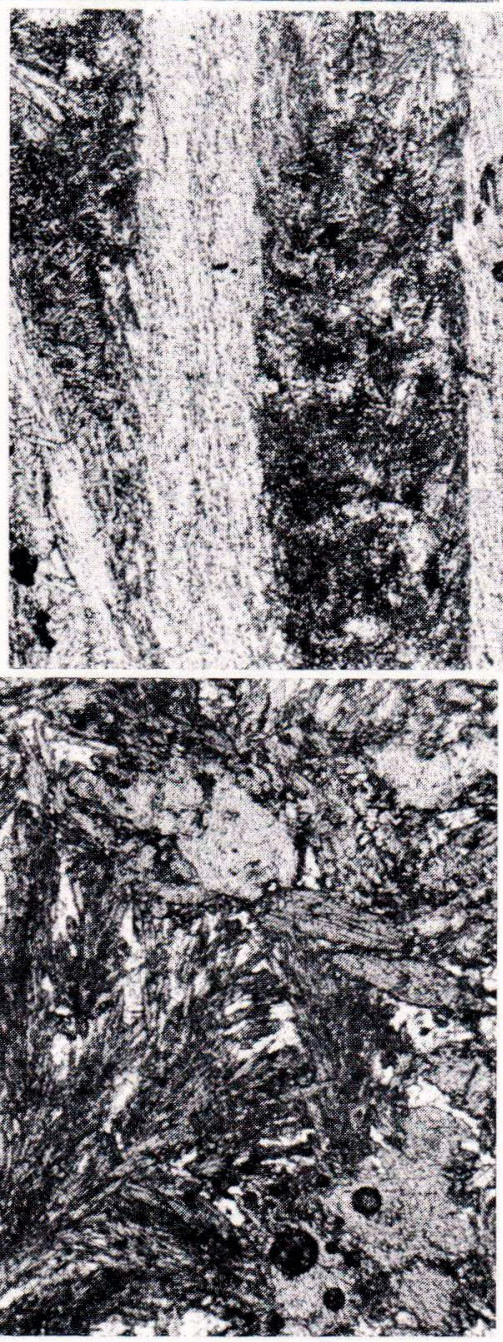

Fig. 12. Plate spinifex texture formed by hornblende pseudomorphs after platy clinopyroxene crystals.

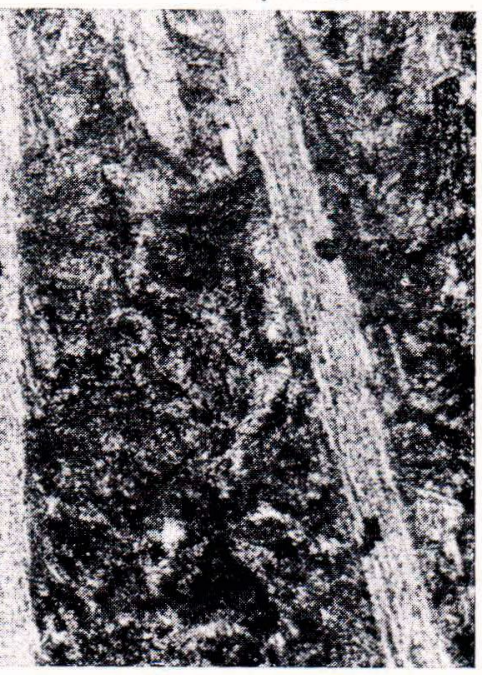

Fig. 14. Photomicrograph of spherulitic intergrowths of hornblende (after clinopyroxene) and plagioclase in interstitial spaces between more coarse-grained, acicular hornblende pseudomorphs of clinopyrcxene. Plane polarized light; photo length $4 \mathrm{~mm}$. 


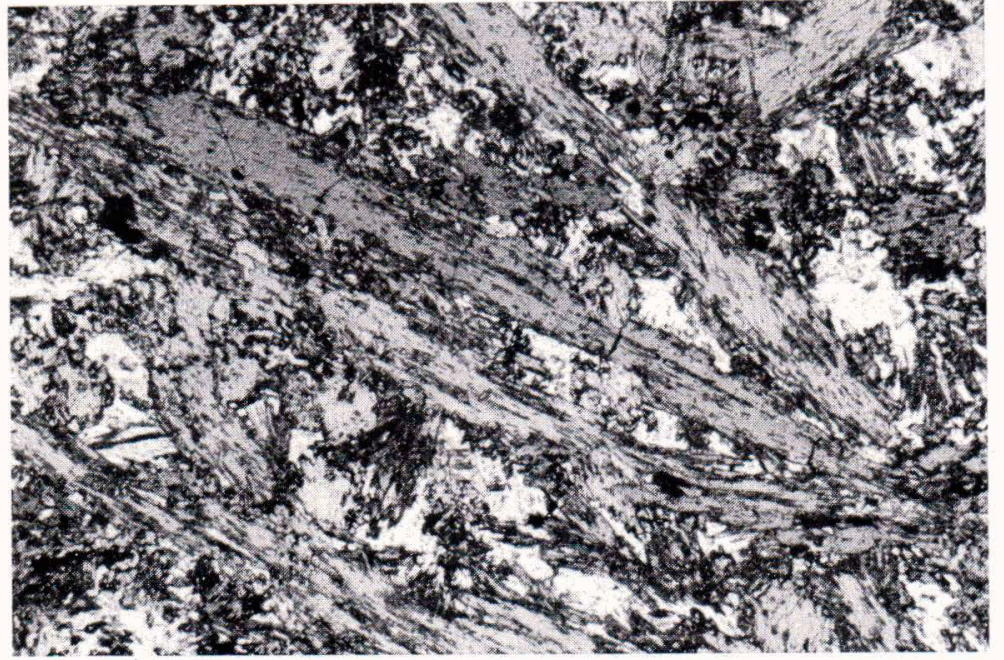

Fig. 15. Photomicrograph of the randomly oriented spinifex type formed originally by acicular clinopyroxene crystals (now hornblende). Interstitial material is plagioclase (white) and hornblende. Plane polarized light; photo length $4 \mathrm{~mm}$ tion, have also been described in pyroxene spinifex-textured flows in Canada (Arndt, $1977 \mathrm{a}, \mathrm{b})$ and in rapidly cooled pyroxenephyric basalts from the moon (Boyd \& Smith, 1971; Weigand \& Hollister, 1973). The latter rocks closely resemble the randomly oriented pyroxene spinifex type in their texture, both in their zoned clinopyroxene phenocrysts and in their interstitial mass composed of an intergrowth of clinopyroxene and plagioclase (see Dowty et al., 1974; Fig. 1 c; Lofgren et al., 1975, Fig. $1 \mathrm{f})$.

The rock in the lower part of zone $A_{2}$ in the thickest lava flows has a texture resembling fine-grained gabbro, the grain size being $0.3-1.5 \mathrm{~mm}$. Whereas the composition of primary plagioclase in komatiitic rocks is usually $\mathrm{An}_{65-85}$ (Jolly, 1975; Whitford \& Arndt, 1978), the plagioclase in the spinifextextured rocks of the Siivikko Member is albite, in spite of the metamorphic environment of the amphibolite facies. This albite problem will be taken up again when considering the geochemistry of the rocks.

Zone $\mathrm{A}_{2}$ also contains pseudomorphs of olivine, which are composed of granoblastic plagioclase mass and chlorite with minor amounts of hornblende. Skeletal forms are still visible in these pseudomorphs, which are some $0.6-4 \mathrm{~mm}$ in size, i.e. larger on average than the chlorite pseudomorphs of the

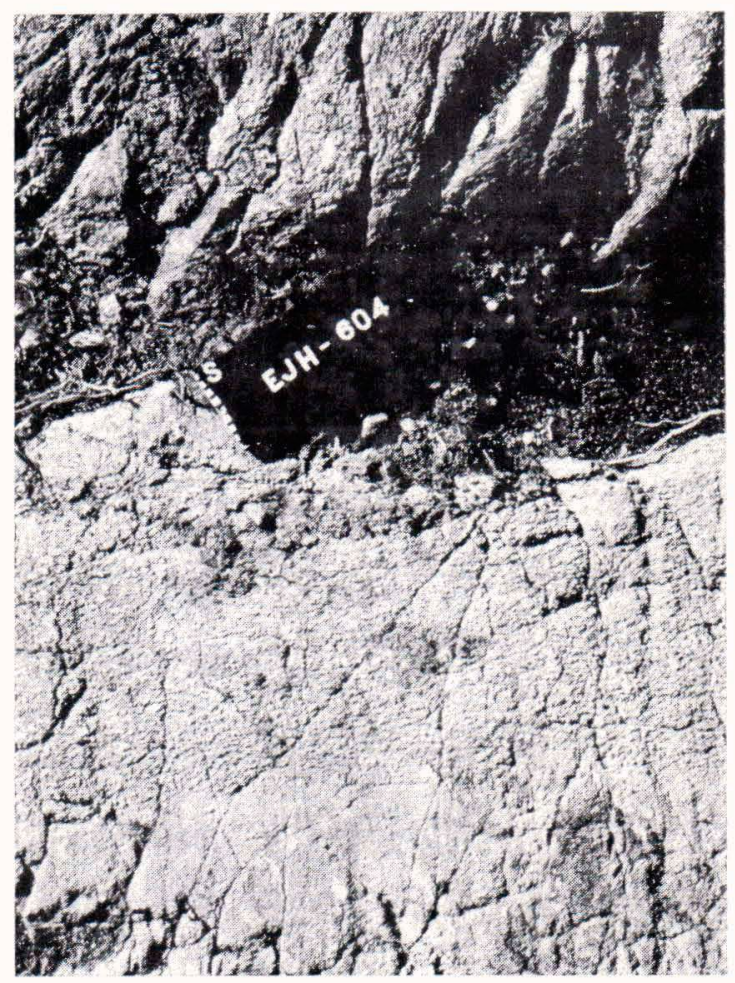

Fig. 16. Zone $B_{1}$ lying between $A_{2}$ an $B_{2}$ in a spinifex-textured lava flow. The length of the number plate is $16.5 \mathrm{~cm}$. 


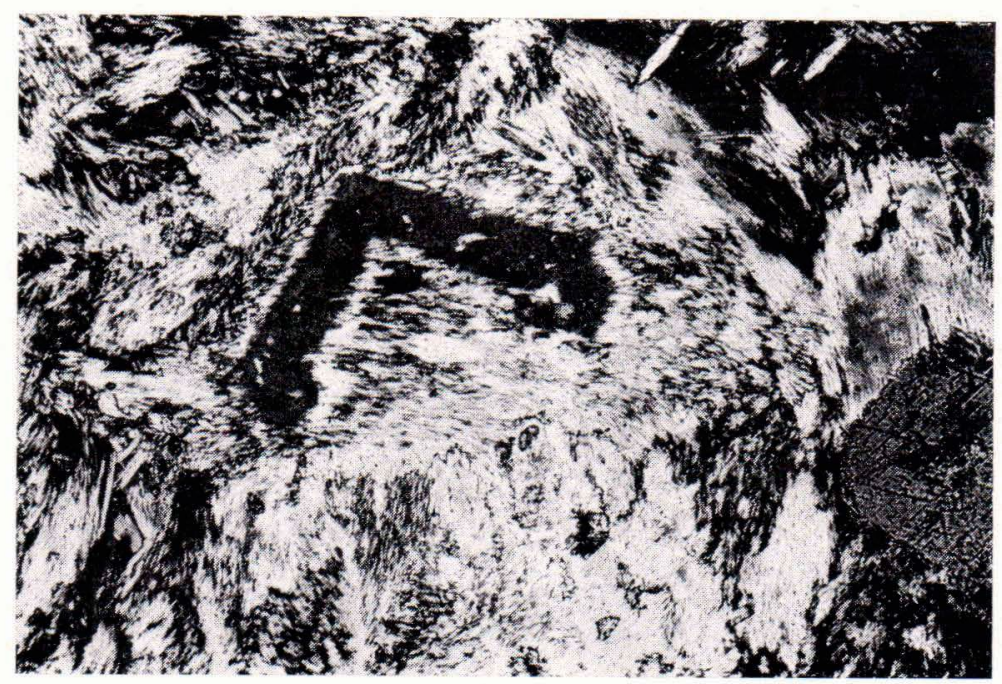

Fig. 17. Photomicrograph of an actinolite pseudomorph after skeletal clinopyroxene in finegrained actinolite mass, zone $\mathrm{B}_{2}$. The pseudomorph shows a cross-section perpendicular to the c-axis and has well-developed (110) faces and subordinate $(010)$ faces. Crossed polars; photo length $1 \mathrm{~mm}$.

flow top breccia. These olivine grains are obviously quench crystals crystallized in situ.

Ilmenite occurs regularly as an accessory mineral in zone $A_{2}$, taking the form of rugged grains $0.2-0.6 \mathrm{~mm}$ in length, and sometimes there exist also pyrrhotite, chalcopyrite and pyrite.

Zone $\mathrm{B}_{1}$, which commences the cumulate zone, is generally $0.2 \mathrm{~m}$ in thickness, although it can be as much as $1 \mathrm{~m}$ thick. A sharply defined boundary exists with the spinifex zone above (Fig. 16), and the rock possesses a distinct foliation in the direction of the bedding. In common with the whole of zone $\mathrm{B}$, zone $\mathrm{B}_{1}$ is entirely ultramafic, being composed of amphibole and chlorite. In contrast to zone $A_{2}$, the amphibole here is light-green, weakly pleochroic actinolite which forms cigar-shaped grains with chlorite cores, smaller skeletal grains and fan-like spherulites. Accessories are prisms of ilmenite and small, euhedral chromite crystals $(\leq 0.05$ $\mathrm{mm})$.

Zone $\mathrm{B}_{2}$ has the appearance of a light-green monotonous rock, but under the microscope it is rather more interesting. Its major minerals are light green actinolite and, in the more magnesium-rich parts, colourless tre- molite and chlorite. The amphibole forms pseudomorphs of skeletal clinopyroxene, the longest of which are $2.5 \mathrm{~mm}$ in extent. Their skeletal character is most in evidence in sections perpendicular to the c axis (Fig. 17), in which one can distinguish complete or incomplete hollow six-sided forms in which four sides, the (110) faces, are well-developed, and two, the (010) faces, are subordinate. These cross-sections sometimes assume a branching form, and sections along the c axis also frequently serve to reveal the hollow interior of the grains. Similar skeletal clinopyroxenes have been described, for instance, by Hallberg et al. (1976, fig. 3) in high-Mg basalts in Western Australia. The amphibole also occurs in the form of fan-like spherulites which are attached by their base to the skeletons described above, or to chlorite pseudomorphs after olivine of size $0.2-1.4 \mathrm{~mm}$. The crystal forms of olivine are often still clearly visible in these pseudomorphs (Fig. 18). As a result of the partial destruction of the texture, it is not possible to calculate the original amount of olivine in zone $\mathrm{B}_{2}$ under a microscope, but point counts made from preserved parts suggest that it is unlikely to have exceeded one third of the whole rock, the remainder having 


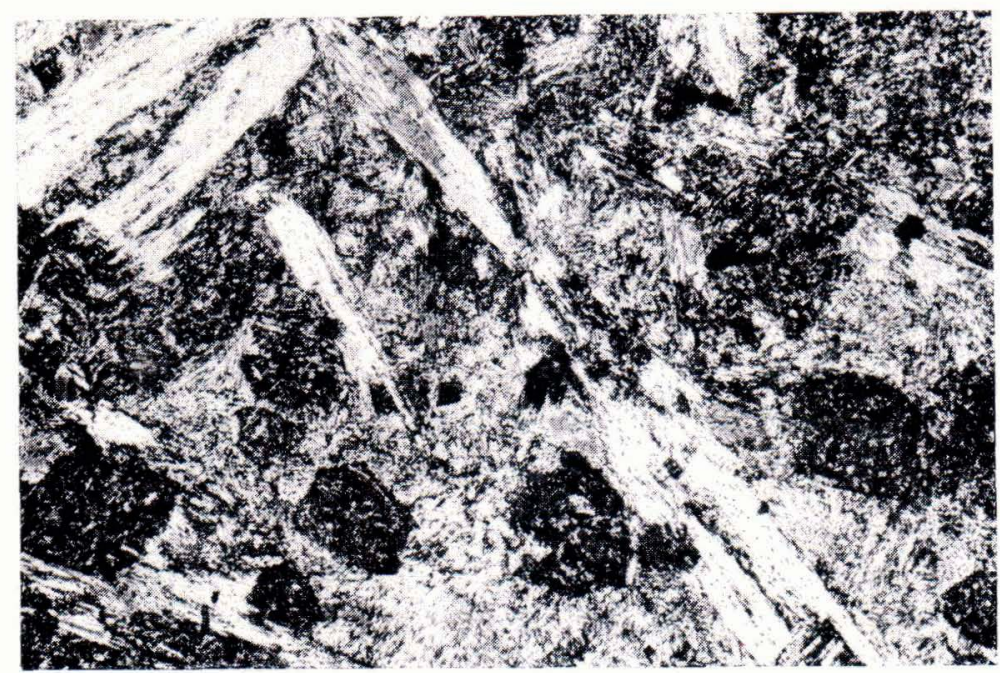

Fig. 18. Photomicrograph of chlorite pseudomorphs after olivine and actinolite pseudomorphs after skeletal and interstitial spherulitic clinopyroxene in zone $\mathrm{B}_{2}$. Crossed polars; photo length $4 \mathrm{~mm}$. consisted mainly of roughly equal amounts of skeletal and spherulitic clinopyroxene grains.

Sometimes talc and carbonate are to be found even as principal minerals as a result of the susceptibility of zone B to carbon dioxide metasomatism. The accessory opaque minerals include both ilmenite prisms and also euhedral and zoned chromite crystals, concentrated in the upper part of zone $\mathrm{B}_{2}$, and pyrrhotite, chalcopyrite and pyrite grains, which in turn are most abundant in the lowest part of the flow.

The cross-section of the spinifex-textured lava flow (Fig. 6) is an idealization. The zone $A_{2}$ does not always divide into two spinifex types, but may consist of the randomly oriented type alone, and the boundary between zones $\mathrm{A}$ and $\mathrm{B}$ may be a gradual one, in which case zone $B_{1}$ is absent and the hornblende of the spinifex zone grades to the actinolite of the cumulate zone within the space of a few decimetres. Zone $\mathrm{A}$ is generally thicker than zone $B$, the average thickness ratio calculated from six cross-sections being $1.2: 1$. Occasionally one finds in the upper part of zone B irregular-shaped spinifextextured fragments varying in size from a few centimetres to several decimetres, which would appear to have fallen from zone $\mathrm{A}_{2}$.

The spinifex texture is generally believed to be the result of rapid in situ crystallization of a crystal-free supercooled liquid (Pyke et al., 1973; Donaldson, 1974; Arndt et al., 1977). This is in agreement with the interpretation that the pyroxene-phyric basalts on the moon have crystallized from a wholly molten lava (Weigard \& Hollister, 1973; Dowty et al., 1974; Lofgren et al., 1975). The systematic variation in the clinopyroxene habit of the spinifex-textured flows of the Siivikkovaara area from dendritic to platy and then to acicular is consistent with experimental results on changes in the shapes of olivine crystals with decreasing cooling rate (Donaldson, 1976). Lofgren et al. (1975) have obtained experimentally a quartz normative basalt with a pyroxene-phyric texture which resembles the randomly oriented spinifex type, using a cooling rate no faster than $2-5^{\circ} \mathrm{C}$ per hour. As pointed out by Donaldson $(1974,1976)$, another factor which greatly affects the degree of supersaturation and the crystal shapes, alongside the cooling rate and degree of supercooling, is the composition of the liquid. Thus the minimum cooling rate at which cer- 
tain crystal habits are produced increases as the normative pyroxene content of the melt decreases. This will affect the habit of clinopyroxene crystals, for spinifex zones can be highly fractionated (Fig. 27) and those rocks with a randomly-oriented spinifex texture seem to have a lower $\mathrm{MgO}$ content than those with a plate spinifex texture. In explaining the origin of the texture of pyroxene-phyric basalts, Lofgren et al. (1974) rely upon the notion put forward by Wyllie (1963) that when one silicate phase is joined in crystallization by another, there is a sharp decrease in the liquidus slope of the system. Once the large acicular pyroxene crystals have been formed, plagioclase joins pyroxene, and the supersaturation in the pyroxene increases because of the change in the liquidus slope. The increasing supersaturation accelerates the nucleation rate of the pyroxene, with the result that spherulitic intergrowths of pyroxene and plagioclase are formed.

Few of the flows in the Siivikko Member are differentiated into spinifex and cumulate zones. Mostly the metalavas are fully ultramafic amphibole-chlorite rocks. Nevertheless, one can sometimes observe macroscopically in these ultramafic rocks microspinifex tex- tures which are composed of actinolite pseudomorphs of platy clinopyroxene several millimetres in length.

\section{Pillow lavas}

The viscosity of the ultramafic magma was sometimes sufficiently high as to permit the formation of pillow lavas. The pillows are light green in colour, with a darker green interstitial mass, and vary in size in the range $0.1-1 \mathrm{~m}$. The direction of the top is generally easy to determine from their curved or bulbous shapes (Fig. 19). The rock is composed mainly of actinolite and chlorite, and the original texture is represented by sporadic amphibole pseudomorphs after dendritic clinopyroxene. The accessories are ilmenite and minor sulphides.

In addition to these ultramafic pillow lavas composed of peridotitic komatiite, the spinifex-textured rocks are also accompanied by thin pillowed interlayers of pyroxenitic komatiite. These dark green pillows, less than $1 \mathrm{~m}$ in size, are composed chiefly of hornblende and small quantities of plagioclase and chlorite, with variolitic textures common.

Fig. 19. Ultramafic pillow lava composed of peridotitic komatiite.

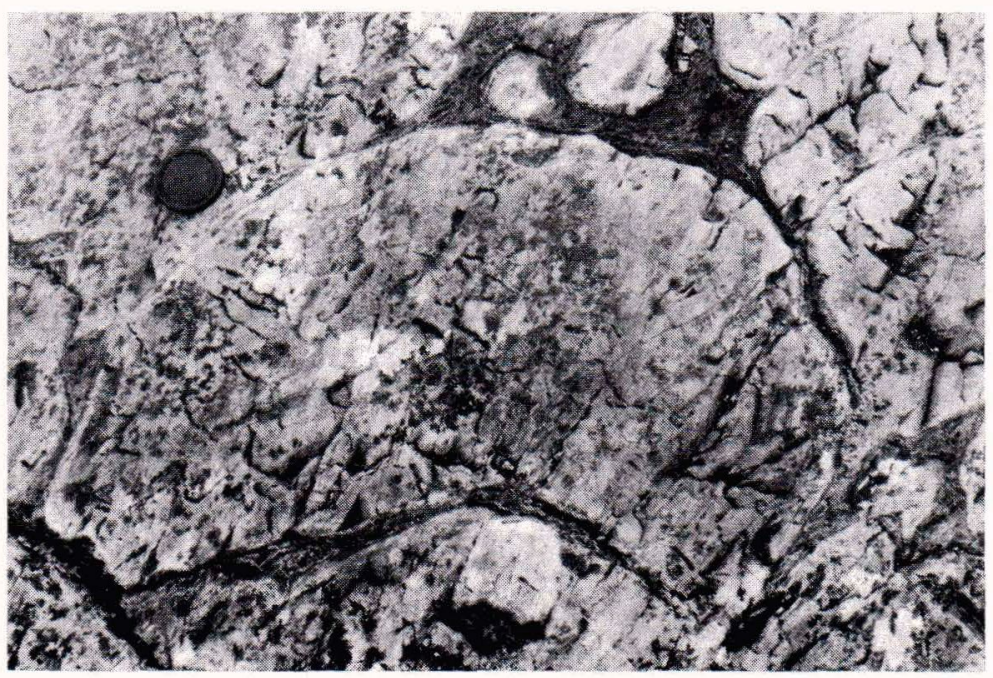




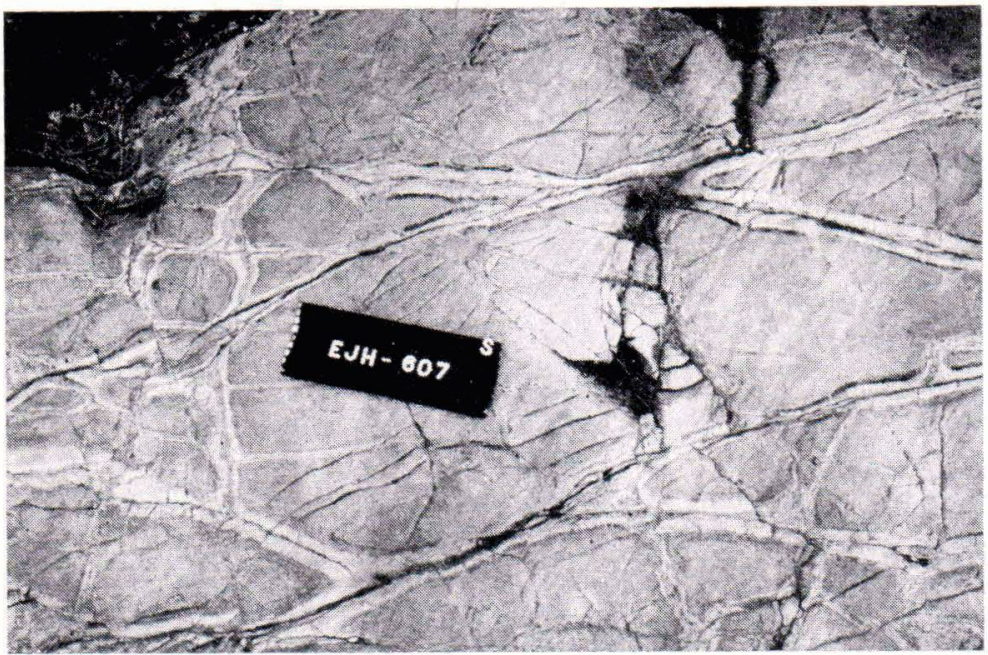

Fig. 20. Polygonal jointing in peridotitic komatiite. The length of the number plate is $16.5 \mathrm{~cm}$.
Polygonal jointing and breccias

The undifferentiated ultramafic metalavas of the Siivikko Member are characterized by an abundance of polygonal jointing (Fig. 20), created as a consequence of thermal contraction as the lava flow cooled. The joints, rimmed with light colour, separate off roundish or angular units varying in size from a few centimetres to almost a metre. This kind of polygonally jointed rock may sometimes grade laterally to autoclastic flow breccia
(Fig. 21) containing large numbers of angular or subangular fragments of size $1-10 \mathrm{~cm}$ with a talc-rich edge $3-8 \mathrm{~mm}$ broad on the weathered surface.

Breccia of a different origin is also to be found in the Siivikkovaara area (Fig. 22). The fragments are ultramafite blocks of dimensions $0.1-1.2 \mathrm{~m}$ with an interstitial mass of clearly oriented mafic metatuff. The blocks are to great extent composed of felted actinolite mass, and the interstitial material of finegrained chlorite and granoblastic plagioclase-

Fig. 21. Autoclastic volcanic breccia in peridotitic komatiite.

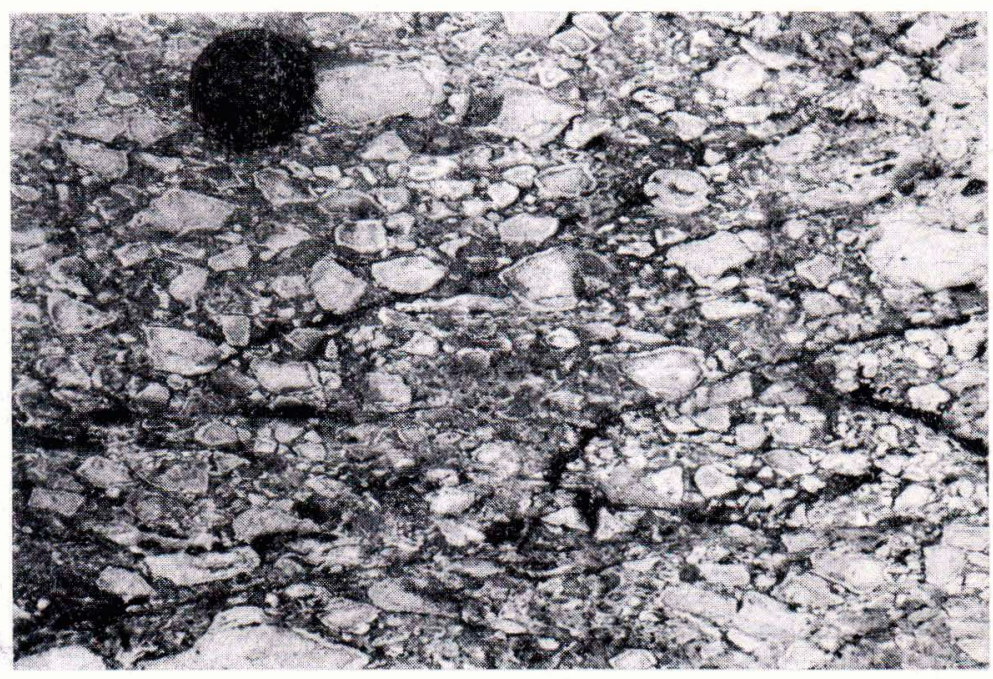




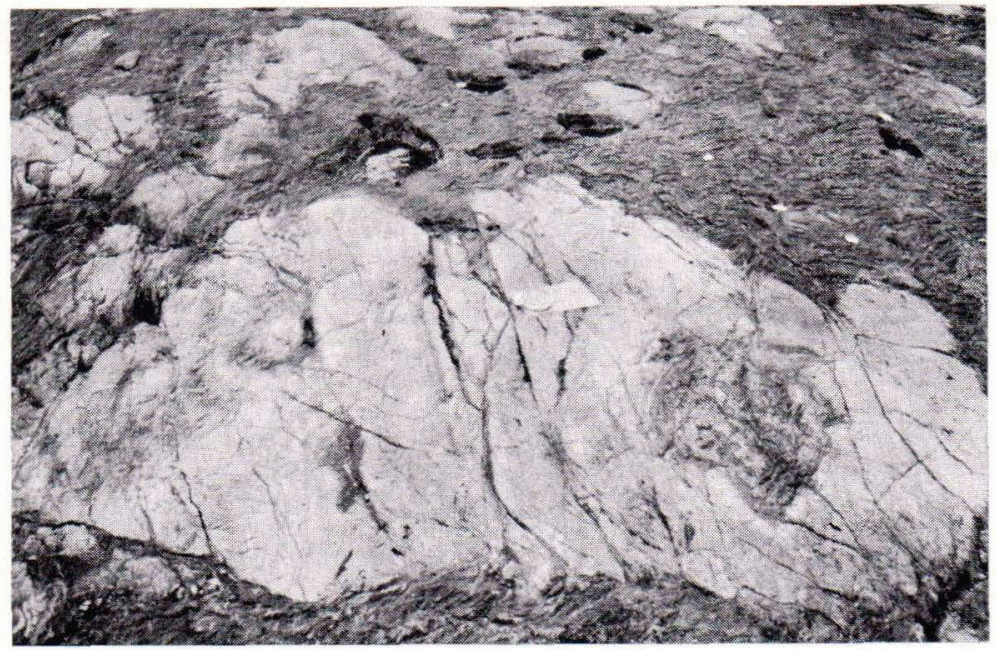

Fig. 22. Coarse volcanic breccia with large ultramafic blocks in a mafic metatuff matrix. The length of the largest block is $1.2 \mathrm{~m}$.

quartz mass and long hornblende porphyroblasts. The breccia probably originated from a mixing of flowing ultramafic lava with unconsolidated mafic tuff material.

\section{Mäkinen M e m b e r}

The Mäkinen Member contains principally dark green pillow lavas composed of pyroxenitic or basaltic komatiite. Only one about ten metres thick interlayer of peridotitic komatiite has been observed in the middle part of the unit. The pillows, which are frequently broken up by a network of narrow plagioclase veins, are generally some $0.4-1.5 \mathrm{~m}$ in size, and are composed largely of green hornblende and varying amounts of plagioclase and chlorite. Ilmenite occurs regularly as an accessory and epidote, sphene, pyrite, zircon and potassium feldspar on occasions. Some rocks, however, are entirely ultramafic, being composed of felted hornblende mass. The original texture is sometimes still very clearly visible, as in the example in Fig. 23, where a small quantity of granoblastic plagioclase mass occurs between the prismatic hornblende grains. The chlorite spots represent original olivine phenocrysts.

The variolitic pillow lavas, which are com- mon particularly in the lower part of the unit, are typically of the structure depicted in Fig. 24, in which the light-coloured centre of the pillow grades through a variole zone to a darker outer zone. Sometimes the varioles are distributed evenly throughout the pillow. These varioles usually vary 1 to 7 $\mathrm{mm}$ in size, and are round or elongated in the direction of lineation. It is possible for two or more such varioles to be combined into one larger entity. A variole is composed mainly of granoblastic plagioclase mass, with additional varying amounts of hornblende, epidote and ilmenite. Somewhat shadowy, long, vary narrow randomly oriented plagioclase needles are sometimes to be seen in them, and they frequently have a hornblende-rich nucleus at the centre, or less often a hornblende-rich zone near their outer edge. The varioles are located in an interstitial mass which varies from ultramafic to mafic, the ultramafic type often presenting the same mosaic texture as is observed in the flow top breccia of a spinifex-textured flow (Fig. 8).

Varioles or ocelli are characteristic features of Archean komatiites (see Viljoen \& Viljoen, 1969 a; McCall \& Leishman, 1971; Hallberg \& Williams, 1972; Nisbet et al., 1977), and have also been encountered in younger 


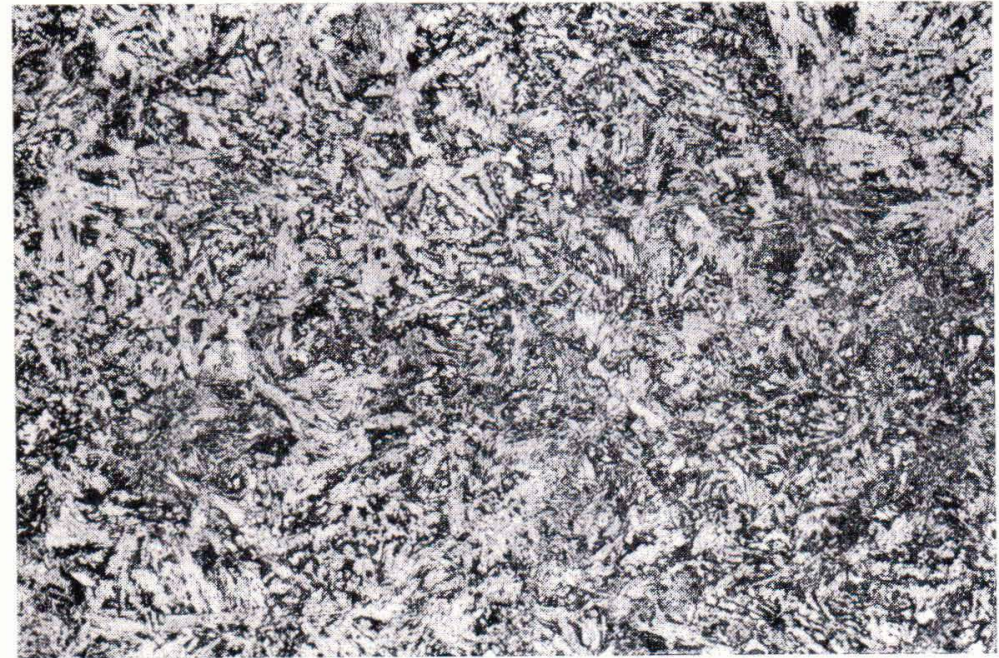

Fig. 23. Photomicrograph of pyroxenitic komatiite from the Mäkinen Member. Acicular actinolite pseudomorphs after clinopyroxene and a little interstitial plagioclase (white). Plane polarized light; photo length $4 \mathrm{~mm}$. komatiites (Upadhyay, 1978) and Mg-rich metalavas (McIver, 1975). Many explanations have been put forward for the origins of a variolitic texture, but the varioles are most frequently regarded as products of spherulitic crystallization of plagioclase with occasional pyroxene (Philpotts, 1977), as devitrification products (Lofgren, 1971; Dimroth \& Lichtblau, 1978), or globules produced by liquid immiscibility in silicate fractions (Ferguson \& Currie, 1972; Furnes, 1973; Gelinas et al., 1976).
$\mathrm{Ra}$ ivio $\mathrm{Me} \mathrm{mber}$

The uppermost unit of the Siivikkovaara Formation, the Raivio Member, contains metatuffs which vary in their composition from ultramafic to mafic. A representative ultramafic sample would have a modal mineral composition as follows: chlorite $48.5 \%$, hornblende $39.9 \%$, plagioclase $7.2 \%$, carbonate $2.3 \%$, biotite $0.7 \%$, epidote $0.5 \%$, sphene $0.5 \%$ and opaques $0.4 \%$. The plagioclase and epidote form narrow bands, while the chlo-
Fig. 24, Variolitic pillow lava in the Mäkinen Member. The length of the number plate is $16.5 \mathrm{~cm}$.

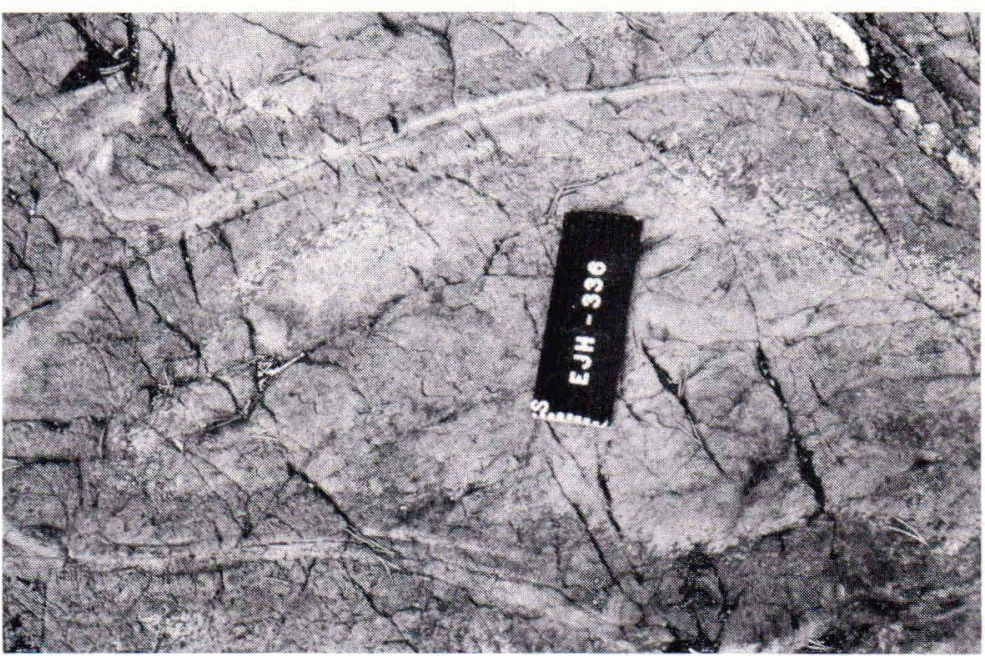


rite occurs as a fine-grained mass and the hornblende forms larger porphyroblasts as much as $1.5 \mathrm{~cm}$ in length, which are often arranged in a layered manner. The mafic metatuffs contain plagioclase, which occurs in the form of a fine-grained granoblastic mass, and also a little quartz. The metatuffs differ both macroscopically and microscopically from the mafic and ultramafic metalavas underlying them.

Gelinas et al. (1975) suggest that ultramafic tuffs are restricted to Archean bedrock. As such, they have been found to date in South Africa (Viljoen \& Viljoen, 1969), Canada (Gelinas et al., 1975, 1977; Kretschmar \& Kretschmar, 1975; Karvinen, 1978) and Australia (McCall, 1973; Sun \& Nesbitt, 1978).

\section{Geochemistry}

\section{Analytical methods}

The majority of the analyses of major and trace elements in rocks from the Kuhmo greenstone belt described here were carried out at the Research Laboratories of the Raahe Steel Works of Rautaruukki Co. mainly using XRF techniques (analyses carrying the abbreviation RR). Sodium and magnesium were determined by the atomic absorption method. Whole rock analyses were also carried out on certain samples by the atomic absorption method in the laboratories of the Department of Geology, University of Oulu (analyses carrying the abbreviation OUDG). In addition, $\mathrm{SiO}_{2}$ was determined spectrophotometrically in all the samples at the latter laboratories from a hydrogen fluoride-boric acid solution (see Abbey et al., 1974) and FeO in some of the samples by potassium permanganate titration. The scandium analyses were performed by the neutron activation method in the reactor laboratory of the State Technological Research Centre.

\section{Tholeiites}

Analyses of metabasalts from the Pahakangas Formation, together with comparative data from the literature, are presented in $\mathrm{Ta}-$ ble 1. According to the classification of Irvine \& Baragar (1971) the metavolcanics of the $\mathrm{Pa}-$ hakangas Formation would be located in the tholeiitic field of the AFM diagram (Fig. 25), while the Jensen cation plot (Jensen, 1976) would place some of the analyses in the calcalkalic field (Fig. 26), an effect which may in part be caused by plagioclase phenocrysts. The iron content is relatively low compared with that of the iron-rich tholeiites normally encountered in Archean bedrock (Pearce \& Birkett, 1974; Arndt et al., 1977), and consequently the $\mathrm{FeO} * / \mathrm{FeO}^{*}+\mathrm{MgO}$ vs. $\mathrm{Al}_{2} \mathrm{O}_{3}$ plot, which is conventionally used to distinguish between komatiites and iron-rich tholeiites, is of no value in the Siivikkovaara area.

The metabasalts of the Pahakangas Formation are typical Archean low-K tholeites (cf. Gill, 1979). Similar tholeiites are widespread in the Eastern Goldfields of Western Australia and Barberton Mountain Land in South Africa, for instance, and it is suggested that they resemble chemically modern oceanfloor basalts (Hallberg \& Williams, 1972; Viljoen \& Viljoen, $1969 \mathrm{~b}$ ). According to Gill (1979), however, Archean low-K tholeiites differ from ocean-floor basalts on account of their low concentrations of $\mathrm{TiO}_{2}$ and high $\mathrm{Ni}$ and $\mathrm{Cr}$, while the difference in $\mathrm{Cr}$ and $\mathrm{Ni}$ content between Archean low-K tholeiites and island arc tholeiites is still greater.

The metavolcanics of the Pahakangas Formation resemble the low-Mg members of the komatiite series in their low $\mathrm{TiO}_{2}$ content, but are not to be regarded as komatiites by virtue of their plagioclase-phyric nature. Their large plagioclase phenocrysts indicate that plagioclase crystallization began at an early stage deep in the earth's crust, whereas the plagioclase in komatiites crystallizes at a 
Table 1. Chemical analyses of metabasalts from the Pahakangas Formation and some comparative analyses from the literature.

\begin{tabular}{|c|c|c|c|c|c|c|c|c|}
\hline & 1 & 2 & 3 & 4 & 5 & 6 & 7 & 8 \\
\hline $\mathrm{SiO}_{2}$ & 52.50 & 51.60 & 49.85 & 50.40 & 50.75 & 50.50 & 49.86 & 51.30 \\
\hline $\mathrm{TiO}_{2}$ & 0.73 & 0.89 & 0.76 & 0.82 & 0.79 & 0.65 & 0.70 & 0.96 \\
\hline $\mathrm{Al}_{2} \mathrm{O}_{3}$ & 15.90 & 17.01 & 15.49 & 14.03 & 15.53 & 14.00 & 14.25 & 14.80 \\
\hline $\mathrm{Fe}_{2} \mathrm{O}_{3}$ & 2.04 & 1.76 & 3.02 & 3.21 & 2.63 & $11.50^{*}$ & - & - \\
\hline $\mathrm{FeO}$ & 7.55 & 8.23 & 8.49 & 8.64 & 7.84 & - & $10.06^{* *}$ & $10.50^{* *}$ \\
\hline $\mathrm{MnO}$ & 0.15 & 0.21 & 0.19 & 0.19 & 0.20 & - & 0.17 & - \\
\hline $\mathrm{MgO}$ & 6.20 & 5.86 & 7.90 & 7.40 & 6.90 & 7.34 & 7.32 & 6.70 \\
\hline $\mathrm{CaO}$ & 10.11 & 9.20 & 10.59 & 12.81 & 11.09 & 11.60 & 10.69 & 10.90 \\
\hline $\mathrm{Na}_{2} \mathrm{O}$ & 2.73 & 2.35 & 1.43 & 1.50 & 2.57 & 2.05 & 2.54 & 2.70 \\
\hline $\mathrm{K}_{2} \mathrm{O}$ & 0.25 & 0.19 & 0.26 & 0.28 & 0.14 & 0.06 & 0.16 & 0.18 \\
\hline $\mathrm{P}_{2} \mathrm{O}_{5}$ & n.d. & n.d. & n.d. & 0.11 & 0.11 & - & 0.05 & 0.12 \\
\hline Ign. loss & 1.70 & 1.64 & 0.91 & 0.79 & 0.59 & 2.30 & 3.29 & 1.20 \\
\hline Total & 99.86 & 98.94 & 98.89 & 100.17 & 99.14 & & & \\
\hline $\mathrm{Cr} \quad(\mathrm{ppm})$ & 550 & 300 & 370 & 360 & 411 & 338 & & 367 \\
\hline $\mathrm{Ni}$ & 220 & n.d. & 165 & 150 & 163 & 122 & - & 170 \\
\hline
\end{tabular}

* Total $\mathrm{Fe}$ as $\mathrm{Fe}_{2} \mathrm{O}_{3}$

** Total $\mathrm{Fe}$ as $\mathrm{FeO}$

1-3. Pillow lava from the Pahakangas Formation (OUDG).

4. Pillow lava from the Pahakangas Formation (RR).

5. Pillow lava from the Pahakangas Formation (analysed in the laboratories of the Geology Department of Rennes University, France).

6. Average composition of tholeiite from the Mafic Formation, Bulawayan Group, Rhodesia (Condie \& Harrison, 1976).

7. Average composition of pillowed tholeite from the Hooggenoeg Formation, Barberton Mountain Land, South Africa (Viljoen \& Viljoen, 1969b).

8. Average composition of 337 tholeiitic metabasalts from Eastern Goldfields, Western Australia (Hallberg \& Williams, 1972).

later stage, after the mafic minerals (Nesbitt \& Sun, 1976; Naldrett \& Cabri, 1976).

\section{Komatiites}

At least ten different classifications for the members of the komatiite series have been proposed in the last ten years, the one favoured in recent years being that of Arndt et al. (1977), which recognizes three types, peridotitic, pyroxenitic and basaltic komatiites, using as its criteria limiting values for $\mathrm{MgO}$ content of $20 \%$ and $12 \%$. Application of this classification as such to the rocks of the Siivikkovaara area nevertheless leads to the assignment of petrographically similar rocks to different types. If, on the other hand, the borderline between the peridotitic and pyroxenitic types were set at $18 \% \mathrm{MgO}$ (in volatile-free analyses), these two types could then also be distinguished with ease in the field: The peridotitic komatiites with light green actinolite or colourless tremolite, differ markedly from the pyroxenitic and basaltic komatiites in being of a distinctly lighter colour, for the dominant mineral in the latter is dark green hornblende. The spinifex-textured lava flows, for instance, contain a clearly distinguishable dark green spinifex zone composed of pyroxenitic and basaltic komatiite and a light green cumulate zone of peridotitic komatiites. A boundary set at $18 \% \mathrm{MgO}$ would also be useful here in the stratigraphical classification, since the Siivikko Member 


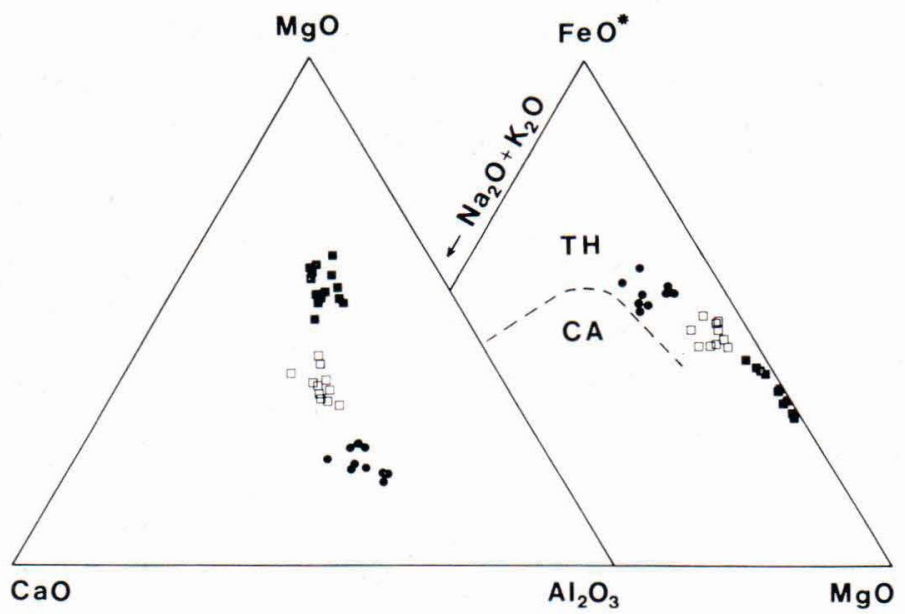

Fig. 25. $\mathrm{CaO}-\mathrm{MgO}-\mathrm{Al}_{2} \mathrm{O}_{3}$ and $\left(\mathrm{Na}_{2} \mathrm{O}\right.$ $+\mathrm{K}_{2} \mathrm{O}$ )-FeO-MgO (wt. $\%$ ) diagrams of metavolcanics of the Kellojärvi group. Symbols: - tholeiites from the Pahakangas formation; $\square$, pyroxenitic and basaltic komatiites from the Mäkinen and Siivikko Members; a, peridotitic komatiites from the Siivikko Member. The boundary between the tholeiitic (TH) and calcalkalic (CA) fields in the AFM diagram is drawn according to Irvine and Baragar (1971).

would then be composed principally of peridotitic komatiites and the Mäkinen Member of pyroxenitic and basaltic komatiites.

Chemical analyses of the komatiites in the Siivikko and Mäkinen Members are presented in Table 2, which serves to emphasize the high $\mathrm{MgO}, \mathrm{Cr}$ and $\mathrm{Ni}$ content in these rocks and the low alkali content of the peridotitic komatiites. The highest values for MgO content measured in the peridotitic komatiites of the Siivikko Member (in volatile-free analyses) reach $24 \%$, while the $\mathrm{CaO} / \mathrm{Al}_{2} \mathrm{O}_{3}$ ratio is

Table 2. Chemical analyses of komatiites from the Siivikko and Mäkinen Members (RR).

\begin{tabular}{|c|c|c|c|c|c|c|c|c|c|}
\hline & 1 & 2 & 3 & 4 & 5 & 6 & 7 & 8 & 9 \\
\hline $\mathrm{SiO}_{2}$ & 45.47 & 45.20 & 42.50 & 46.90 & 48.90 & 47.50 & 47.70 & 48.70 & 48.90 \\
\hline $\mathrm{TiO}_{2}$ & 0.33 & 0.40 & 0.61 & 0.51 & 0.68 & 0.60 & 0.68 & 0.63 & 0.71 \\
\hline $\mathrm{Al}_{2} \mathrm{O}_{3}$ & 7.81 & 8.35 & 11.21 & 8.41 & 10.90 & 11.30 & 11.32 & 9.88 & 12.73 \\
\hline $\mathrm{FeO}^{*}$ & 9.61 & 10.96 & 12.62 & 11.02 & 12.54 & 12.08 & 13.34 & 12.19 & 12.13 \\
\hline $\mathrm{MnO}$ & 0.19 & 0.18 & 0.20 & 0.20 & 0.28 & 0.32 & 0.28 & 0.23 & 0.21 \\
\hline $\mathrm{MgO}$ & 22.04 & 21.80 & 19.40 & 19.00 & 11.80 & 12.60 & 12.00 & 13.60 & 11.10 \\
\hline $\mathrm{CaO}$ & 7.46 & 5.59 & 6.65 & 8.35 & 9.32 & 11.02 & 10.57 & 9.24 & 7.72 \\
\hline $\mathrm{Na}_{2} \mathrm{O}$ & 0.28 & 0.20 & 0.18 & 0.07 & 2.18 & 1.08 & 1.40 & 2.04 & 3.15 \\
\hline $\mathrm{K}_{2} \mathrm{O}$ & 0.01 & 0.01 & 0.01 & 0.01 & 0.26 & 0.15 & 0.15 & 0.07 & 0.09 \\
\hline $\mathrm{P}_{2} \mathrm{O}_{5}$ & 0.00 & 0.02 & 0.05 & 0.05 & 0.09 & 0.07 & 0.09 & 0.02 & 0.07 \\
\hline Ign. loss & 5.80 & 6.27 & 6.09 & 5.18 & 1.96 & 2.15 & 1.89 & 2.58 & 2.50 \\
\hline Total & 99.00 & 98.98 & 99.52 & 99.70 & 98.91 & 98.87 & 99.42 & 99.18 & 99.31 \\
\hline Co (ppm) & 90 & 80 & 90 & 100 & 70 & 60 & 70 & 70 & 50 \\
\hline $\mathrm{Cr}$ & 2450 & 2620 & 1540 & 1300 & 1010 & 1090 & 760 & 1260 & 580 \\
\hline $\mathrm{Cu}$ & 40 & 10 & 0 & 10 & 170 & 10 & 0 & 0 & 30 \\
\hline $\mathrm{Ni}$ & 1110 & 1040 & 680 & 890 & 660 & 390 & 330 & 390 & 180 \\
\hline
\end{tabular}

1-2. Peridotitic komatiite, massive lava, Siivikko Member.

3. Peridotitic komatiite, microspinifex texture, Siivikko Member.

4. Peridotitic komatiite, cumulate zone of a spinifex-textured lava flow, Siivikko Member.

5-6. Pyroxenitic komatiite, massive lava, Mäkinen Member.

7. Pyroxenitic komatiite, pillow lava, Siivikko Member.

8. Pyroxenitic komatiite, pillow lava, Mäkinen Member.

9. Basaltic komatiite, spinifex texture, Siivikko Member. 

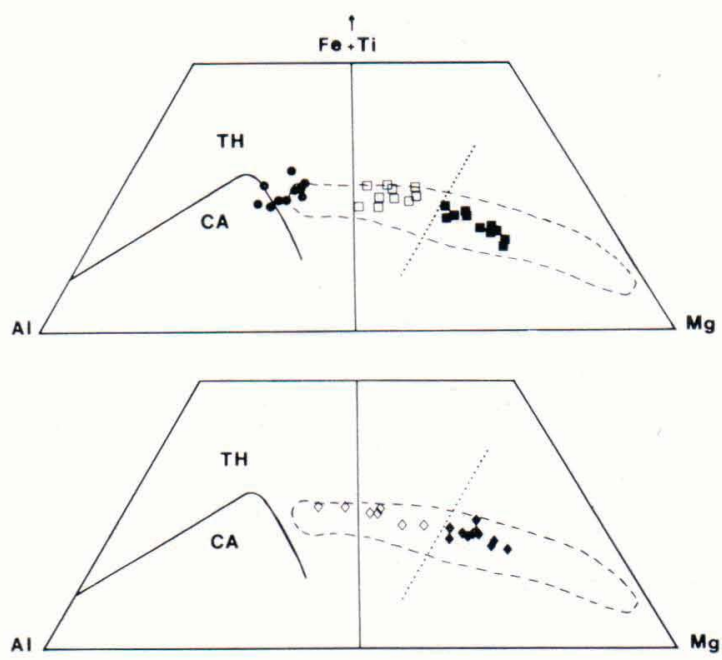

often less than 1, in contrast with the high figures reported in Barberton Mountain Land by Viljoen \& Viljoen (1969 a). The analyses form typical komatiite trends in the Jensen cation plot (Fig. 26) and on the CMA diagram (Fig. 25). Jensen (1976) originally set the boundary between ultramafic and basaltic komatiites in his cation plot at an $\mathrm{Mg}$ value of $70 \%$. This boundary was then reduced to $60 \% \mathrm{Mg}$ by Francis \& Hynes (1979), who refer to the two areas thus delimited as the »mafic komatiite field» and the »ultramafic komatiite field». The peridotitic komatiites of the Siivikkovaara area, which are entirely ultramafic, nevertheless show $\mathrm{Mg}$ values in the Jensen plot which fall as low as $53 \%$ (Fig. 26).

In places in the metalavas of the Siivikko Member there exist microspinifex textures in which spherulitic amphibole pseudomorphs after clinopyroxene occur in between platy amphibole pseudomorphs after clinopyroxene and platy chlorite pseudomorphs after olivine, both a few millimetres in length. The $\mathrm{MgO}$ content of such a rock may exceed $20 \%$ (in volatile-free analysis). The $\mathrm{MgO}$ content figures obtained for the liquid compositions of the volcanics of the Siivikko Member vary
Fig. 26. Jensen cation plots for the metavolcanics of the Kellojärvi Group. Symbols: tholeiites from the Pahakangas Formation; $\square$, pyroxenitic and basaltic komatiites from the Mäkinen and Siivikko Member; $\mathbf{a}$, peridotitic komatiites from the Siivikko Member; $\diamond$, spinifex zone; cumulate zone of the spinifex-textured lava flows. The dashed line representing the komatiite field is drawn by reference to over 700 analyses of volcanic komatiites of which the majority have been collected from the literature and the remainder analysed from the Kuhmo greenstone belt. The list of references is available from the author on request.

from $7.7 \%$ (Table 3 , analysis 9) to slightly over $20 \%$, although lying closer to the latter value for the most part because of the totally ultramafic nature of most of the metalavas.

A spinifex-textured lava flow

Table 3 depicts the results of analyses carried out on one spinifex-textured lava flow of thickness $15.6 \mathrm{~m}$. Analyses $1-7$ are from the cumulate zone and no. 13 from the flow top breccia. The spinifex texture (represented by analyses 8 - 10) under the $1.5 \mathrm{~m}$ thick dendrite zone (analyses 11 and 12) is formed of randomly-oriented hornblende needles. The boundary between the spinifex and cumulate zones is gradual.

The weighted average composition of the flow (analysis no. 14, Table 3) shows a $\mathrm{MgO}$ content of $16.73 \%$ (in volatile-free analysis), thus corresponding to pyroxenitic komatiite. The chilled flow top breccia, which is usually taken to represent the composition of the undifferentiated magma, nevertheless proves to be peridotitic komatiite, with a $\mathrm{MgO}$ content of $19.89 \%$ (dry). This discrepancy can be attributed either to an error in analysis or to the presence in the sample of an unusually 


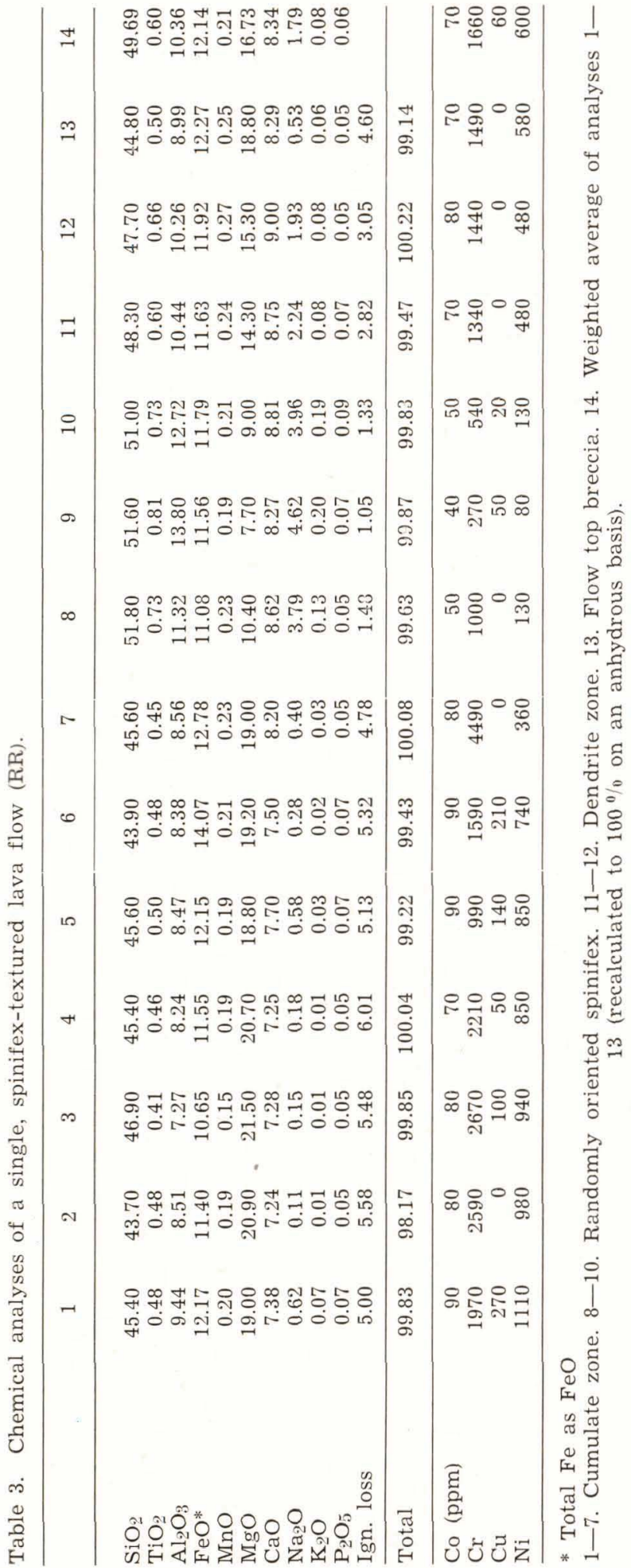

large number of olivine phenocrysts. Such a large error in analysis would be improbable, however, and both the present mineralogy and also the even, light green colour of the flow top breccia suggest that this high magnesium content is a reality throughout the breccia. It has been shown by Seyfried et al. (1979) and Seyfried \& Bischoff (1979) that the glassy rim of a pillow lava may lose $\mathrm{SiO}_{2}$ and gain $\mathrm{MgO}$ by interaction with sea water, and this may have been the case with the present flow top breccia, which would explain its high $\mathrm{MgO}$ and low $\mathrm{SiO}_{2}$ content. The $\mathrm{Na}_{2} \mathrm{O}$ content also differs considerably in analyses 13 and 14 of Table 3 .

The variation in chemical components in different parts of the lava flow is shown in Fig. 27, in which the advanced stage of differentiation is readily observable. With the exception of $\mathrm{Na}_{2} \mathrm{O}$ and $\mathrm{CaO}$, the distribution of components resembles that described by Arndt (1977 b) in Fred's Flow, of thickness $120 \mathrm{~m}$. The $\mathrm{MgO}$ content varies greatly as a function of depth (Fig. 27), as a consequence of the ultramafic character of the cumulate zone and the mafic character of the spinifex zone. The fact that the curve for nickel follows this same pattern suggests that nickel was once bound mainly to the olivine, except in the lower part of the lava flow, where small quantities of sulphides occur. The chromium curve also follows that for $\mathrm{MgO}$ to a great extent, except in the upper part of the cumulate zone, where chromium is strongly enriched due to the presence of chromite grains. In olivine spinifex-textured lavas chromium is generally enriched in the spinifex zone itself as a result of the late crystallization of chromite (see Barnes et al., 1974), but in the pyroxene spinifex-textured lavas of the Siivikkovaara area the chromite crystallized relatively early due to the pyroxenitic bulk composition of the flows and has accumulated in the upper part of zone $\mathrm{B} . \mathrm{Na}_{2} \mathrm{O}$ 


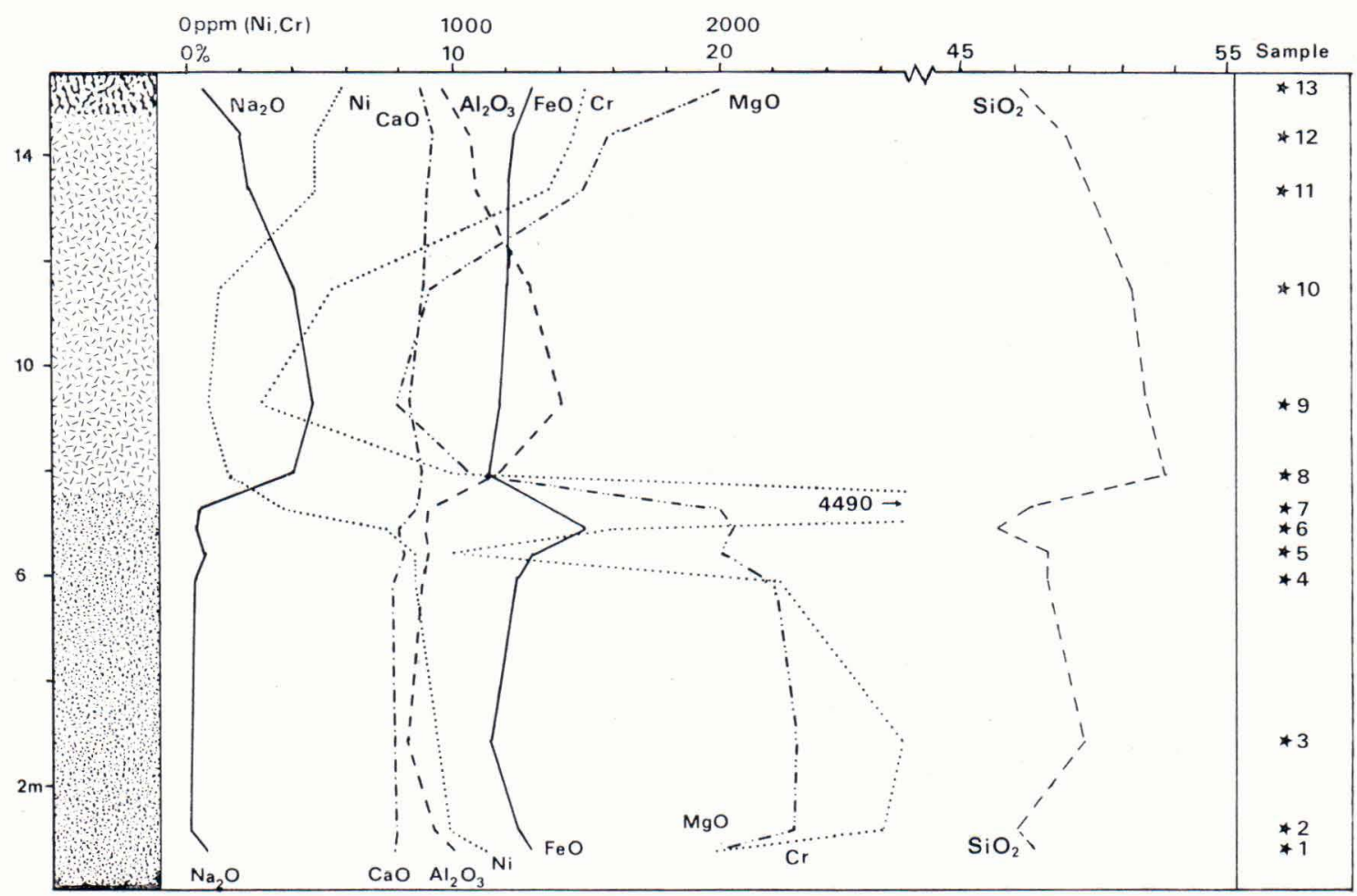

Fig. 27. Graphical presentation of analyses $1-13$ in Table 3 (volatile free) from a differentiated spinifex-textured lava flow.

and $\mathrm{Al}_{2} \mathrm{O}_{3}$ behave in entirely the opposite manner from magnesium oxide, since they tend to bind to the light-coloured minerals, whereas $\mathrm{MgO}$ favours the mafic minerals. Significant features to emerge from Fig. 27 are the high $\mathrm{Na}_{2} \mathrm{O}$ content of the lower part of the spinifex zone and the similarity between the $\mathrm{Na}_{2} \mathrm{O}$ and $\mathrm{Al}_{2} \mathrm{O}_{3}$ curves, the reasons for which lie in the binding of these components to albitic plagioclase, which occurs in large amounts, especially in the lower part of the spinifex zone.

The first explanation which comes to mind for the presence of albite in a metamorphic environment is naturally recrystallization occurring either in the greenschist or the albite - epidote - amphibolite facies. The dominant facies in the Siivikkovaara area, however, is an amphibolite facies, and albite is concentrated almost exclusively in the spi- nifex-textured rocks. Also, the recrystallization of a plagioclase containing anorthite to form albite would involve the release of calcium, which would form epidote. Only a few grains of epidote have been encountered, however, so that the excess calcium would have had to have been removed from the rock. If the An content of the plagioclase before metamorphism was $65-85 \%$, an impossibly large amount of calcium would have had to have left the rock in order to give a $\mathrm{Na}_{2} \mathrm{O}$ content as high as $4.68 \%$ (dry), in addition to which no evidence is to be found anywhere of any mineral formed from the released calcium. The distribution of components described in Fig. 27 is such that it would seem impossible to achieve such a high $\mathrm{Na}_{2} \mathrm{O}$ content otherwise than through some addition of external sodium. On the other hand, there is no evidence in the Siivikko- 
vaara area of any extensive sodium metasomatism having taking place at the time of metamorphism. It is thus evident that the plagioclase must have been albitic in composition before metamorphism. This is also supported by the fact that the analyses of those rocks from the spinifex zone which contain high proportions of albite are located at the point representing the composition of hornblende in the ACF diagram for the amphibolite facies.

If the plagioclase had crystallized originally as albite, the magma ought to have been rich in $\mathrm{Na}$. The possibility of a high sodium content in a komatiitic magma is a remote one, however. In Fred's Flow, for example, a gabbroic differentiate with $7.7 \% \mathrm{MgO}$ (dry) has only $1.62 \% \mathrm{Na}_{2} \mathrm{O}$ (Arndt, $1977 \mathrm{~b}$ ). If we, nevertheless, assume that the figure of $1.79 \%$ for the $\mathrm{Na}_{2} \mathrm{O}$ content in the total composition of the lava flow (Table 3, analysis 14) represents the $\mathrm{Na}_{2} \mathrm{O}$ content of the original magma, the high values for the spinifex zone must then be attributed to fractional crystallization. It can be demonstrated, however, that the fractionation of olivine or clinopyroxene from a magma corresponding to the results of analysis 14 cannot give a residual magma with a $\mathrm{Na}_{2} \mathrm{O}$ content of more than $3 \%$, not to mention the case in which the mineral for fractionation is plagioclase. One could achieve a $\mathrm{Na}_{2} \mathrm{O}$ content of approx. $3.5 \%$ by extracting orthopyroxene, but the pseudomorphs and the chemistry of the rocks do not provide any evidence for an accumulation of orthopyroxene in the lavas described here. Olivine, with a composition of $\mathrm{Fo}_{88.3}$ (Arndt et al., 1977, table 2, analysis SA2048) could crystallize out from this magma to an extent of approx. 35 wt.- $\%$, exhausting the magnesium oxide, but even then the $\mathrm{Na}_{2} \mathrm{O}$ content of the residual magma would be no more than $2.8 \%$.

The only feasible explanation for the high sodium and albite content of the spinifextextured rocks would thus seem to be sodium metasomatism occurring soon after the crystallization of the lava flows, the necessary additional sodium being obtained from sea water. Since the plagioclase would scarcely have been albitic originally, but rather rich in $\mathrm{An}$, the variation in $\mathrm{CaO}$ between the various parts of the lava flows should reflect the proportions of plagioclase. But the calcium oxide content remains practically constant throughout the spinifex zone, from which we can only assume a loss of calcium upon the addition of sodium. The rock was presumably already in crystalline form at the time of sodium metasomatism, as this seems to have affected only the rock containing plagioclase, the $\mathrm{Na}$ content of the flow top breccia ( $\mathrm{Ta}$ ble 3 , analysis 13) remaining very much lower than that of the bulk composition of the lava (Table 3, analysis 14).

The differentiation in the lava flows was studied by means of molar ratio diagrams, the theoretical background to which is examined by Pearce (1968). Fig. 28 depicts the relation-

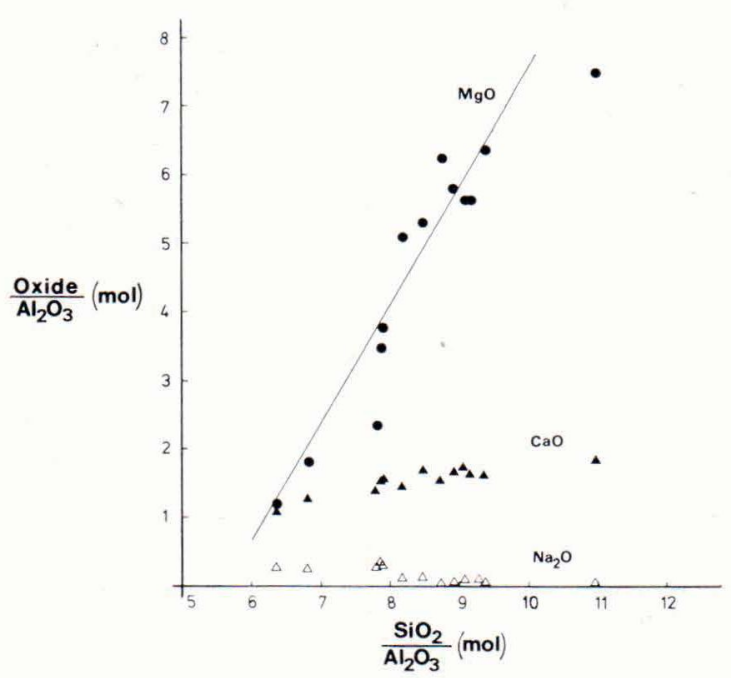

Fig. 28. Relationship of $\mathrm{MgO}, \mathrm{CaO}$ and $\mathrm{Na} 2 \mathrm{O}$ to $\mathrm{SiO}_{2}$ as a molar ratio diagram using $\mathrm{Al}_{2} \mathrm{O}_{3}$ as the denominator in a differentiated spinifex-textured lava flow. Analyses $1-13$ from Table 3 . 
ship of $\mathrm{MgO}, \mathrm{CaO}$ and $\mathrm{Na}_{2} \mathrm{O}$ to $\mathrm{SiO}_{2}$ on a molar ratio diagram with $\mathrm{Al}_{2} \mathrm{O}_{3}$ as the denominator (Table 3 , analyses $1-13$ ). The points in the plot of $\mathrm{SiO}_{2} / \mathrm{Al}_{2} \mathrm{O}_{3}$ vs. $\mathrm{MgO} / \mathrm{Al}_{2} \mathrm{O}_{3}$ yield a steeply rising regression line. The data used in drawing this line exclude analyses 3 and 8, in which the expected opposing behaviour of $\mathrm{MgO}$ and $\mathrm{SiO}_{2}$ is not observed (see Fig. 27). The slope of this line would correspond to the fractionation of an olivine with a forsterite content of $86 \%$. If it had been a matter of the fractionation of clinopyroxene alone, the slope of the line would have been very much lower, around $0.4-0.5$, and in the case of orthopyroxene around 0.8 .

It is easiest to demonstrate the involvement of clinopyroxene in the differentiation of the lava flows on the basis of the diagram for $\mathrm{SiO}_{2} / \mathrm{Al}_{2} \mathrm{O}_{3}$ vs. $\mathrm{CaO} / \mathrm{Al}_{2} \mathrm{O}_{3}$ (Fig. 28), in which the points assume a shallow rising trend indicative of a low level of clinopyroxene fractionation. It should be borne in mind, however, that albite is assumed to have been formed through sodium metasomatism, with an accompanying loss of calcium from the rock, as a result of which the original division of the calcium will not be shown in Fig. 28. The sodium metasomatism is visible in the diagram in the form of a jump in the ratio $\mathrm{Na}_{2} \mathrm{O} / \mathrm{Al}_{2} \mathrm{O}_{3}$. The molar ratio diagram using the sum of $\mathrm{Na}_{2} \mathrm{O}$ and $\mathrm{CaO}$ provides a better impression of the behaviour of clinopyroxene (Fig. 29), since here the regression line, which is for all practical purposes horizontal, would eliminate entirely any fractionation of clinopyroxene.

When examining Figs. 28 and 29 one should also take into consideration the high $\mathrm{Al}_{2} \mathrm{O}_{3}$ content of clinopyroxenes in komatiitic rocks (Fleet \& MacRae, 1975). If there had been any accumulation of clinopyroxene, the amount of $\mathrm{Al}_{2} \mathrm{O}_{3}$, which served as the denominator in the diagrams, would have diminished in the residual liquid as differentiation proceeded.

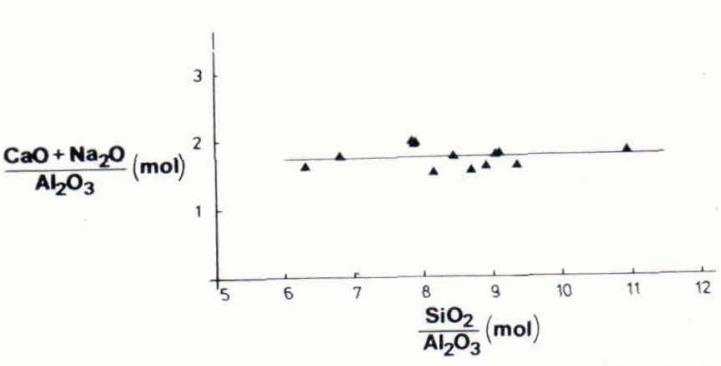

Fig. 29. The observed relationship of $(\mathrm{CaO}+$ $\left.\mathrm{Na}{ }_{2} \mathrm{O}\right) / \mathrm{Al}_{2} \mathrm{O}_{3}$ vs. $\mathrm{SiO}_{2} / \mathrm{Al}_{2} \mathrm{O}_{3}$ for a differentiated spinifex-textured lava flow. Analyses 1-13 from Table 3 .

Any reduction in the denominator would result in a reduction in the slope of the regression lines, on the basis of which one could question the result depicted in Fig. 29. Similarly, the line indicating the fractionation of olivine in Fig. 28 would be too shallow on these grounds, which would in turn support the notion of olivine fractionation, however. Also, the forsterite content of the olivine calculated from the slope of the regression line is in agreement with the $\mathrm{MgO}$ content values for the spinifex zone (cf. Duke \& Naldrett, 1978).

The molar ratio diagrams thus lead us to the conclusion that if any clinopyroxene fractionation has occurred, it has been only minor in extent by comparison with the fractionation of olivine. Admittedly, changes in silica or alumina content could have taken place at the time of sodium metasomatism, but on the other hand, the same conclusions can also be reached taking $\mathrm{TiO}_{2}$ as the denominator. Extraction of $\mathrm{CaO}$ from the spinifex zone during sodium metasomatism would have increased the slopes of the regression lines in the plots of $\mathrm{CaO} / \mathrm{Al}_{2} \mathrm{O}_{3}$ vs. $\mathrm{SiO}_{2} / \mathrm{Al}_{2} \mathrm{O}_{3}$ and $\mathrm{CaO}+\mathrm{Na}_{2} \mathrm{O} / \mathrm{Al}_{2} \mathrm{O}_{3}$ vs. $\mathrm{SiO}_{2} / \mathrm{Al}_{2} \mathrm{O}_{3}$, and thus this cannot have eliminated the effects of clinopyroxene fractionation in these diagrams. Also, the results of the molar ratio diagrams are in agreement with the concept of a negative correlation of $\mathrm{Sc}$ with $\mathrm{Ni}$ and 

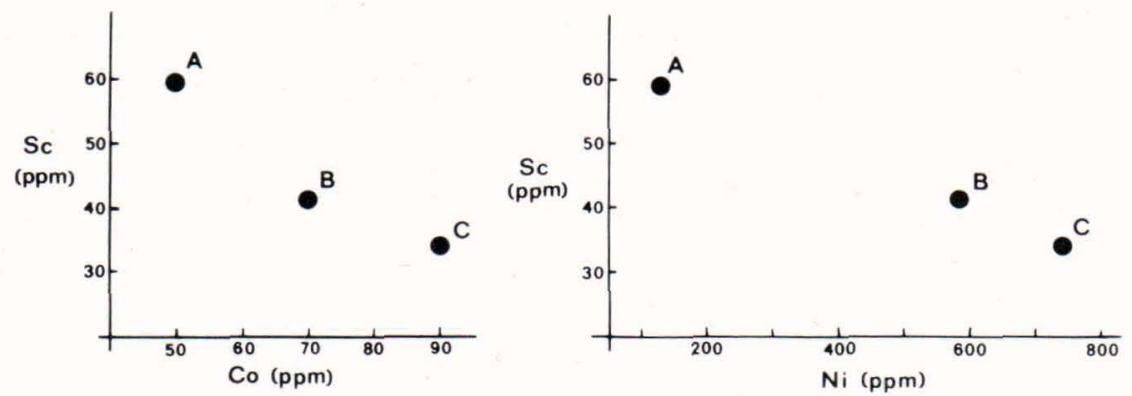

Fig. 30. Variation of $\mathrm{Sc}$ with $\mathrm{Co}$ and $\mathrm{Ni}$ in a spinifex-textured lava flow. Samples (anal. 6, 8, 13, Table 3): A, spinifex zone; B, top breccia; C, cumulate zone.

Co, as seen in Fig. 30. The clinopyroxene-melt distribution coefficients for these elements are all greater than unity (see Sun et al., 1979), i.e. if clinopyroxene had been the only fractionating mineral the points would have been arranged on a rising line. The olivinemelt distribution coefficients for $\mathrm{Ni}$ and $\mathrm{Co}$ are also $>1$, but that for $\mathrm{Sc}<1$ (Arndt, 1977 c; Sun et al., 1979), so that with the fractionation of olivine the residual melt becomes enriched with respect to scandium but impoverished with respect to nickel and cobalt.

Experimental research suggests that clinopyroxene begins to crystallize from a komatiitic magma at a pressure of $1 \mathrm{~atm}$ once the $\mathrm{MgO}$ content of the liquid has dropped to about $9 \%$ (Arndt, 1976). Since the lowest $\mathrm{MgO}$ content in the rocks analysed here from the spinifex zone is $7.7 \%$, one may conclude that a small amount of clinopyroxene fractionation must have taken place, as evidenced by the presence of large amphibole pseudomorphs of clinopyroxene with chlorite cores in zone $B_{1}$. In summary, it may then be stated that the differentiation of the spinifex-textured lava flows was caused by the settling down of olivine, and to a lesser extent by that of clinopyroxene and chromite.

The large actinolite pseudomorphs of skeletal clinopyroxene (see Figs. 17 and 18) in the cumulate zone are thus not cumulus grains precipitated downwards from the spinifex zone, but have crystallized in situ. This interpretation gains support from the fact that there are differences in morphology between the hornblende pseudomorphs in the spinifex zone and the actinolite pseudomorphs in the cumulate zone, the former being solid and frequently containing chlorite cores, whereas the latter are often skeletal with hollow cores. The higher silica and alkali contents of the spinifex zone evidently enable the formation of pigeonite cores in the clinopyroxene grains.

The MgO content of the spinifex-textured rocks in the area studied here is mostly in the range $11-13 \%$. The flow top breccia of the differentiated lava flow discussed above (Table 3, Fig. 27) has been found by means of point counting carried out on one thin section to contain about $15 \%$ chlorite pseudomorphs of olivine phenocrysts. If this $15 \%$ olivine is excluded from the bulk composition of the lava flow (Table 3, analysis 14), which corresponds better to the composition of the parent magma than does the surface breccia, the $\mathrm{MgO}$ content then drops to $11-$ $12 \%$. If such $\mathrm{MgO}$ values really represent the $\mathrm{MgO}$ content of the liquid, it is difficult to explain the totally ultramafic character of the cumulate zone, since as previously stated, the modal cumulus olivine content of the cumulate zone can hardly have exceeded one third of the rock. 
Over two-thirds of the rock consisted mainly of skeletal and spherulitic clinopyroxene grains crystallized in situ, and it is thus probable that the original liquid may have been more basic than most of the spinifex-textured rocks, which have crystallized to mafic rocks consisting of clinopyroxene and plagioclase (and also pigeonite). Consequently, either the amount of olivine phenocrysts estimated to be present in the flow top breccia, $15 \%$, does not represent that in the breccia as a whole, or else some of the phenocrysts are quench crystals formed in situ. Some of the phenocrysts do show skeletal forms, but the details of their form have mostly been destroyed in the process of pseudomorphism. Possible representatives of the primary liquid are either samples from the dendrite zone composed originally of clinopyroxene, glass, olivine and minor amounts of plagioclase, or else samples from the spinifex-textured rock immediately below the dendrite zone. If, for example, the analysis of the lower part of the dendrite zone, with a $\mathrm{MgO}$ content of $14.8 \%$ (Table 3, analysis 11) is taken to correspond to the primary liquid in composition, assuming olivine to be the only fractionating mineral, this would imply that the magma contained about $7 \%$ olivine phenocrysts which were precipitated in the cumulate zone to give an average of about $14 \%$ olivine phenocrysts. Later an additional $10 \%$ of the olivine grains crystallized and settled down from the above liquid.

The above discussion suggests that the crystallization behaviour of the liquid was quite different in the upper and lower sections of the spinifex-textured lava flows, and judging from the spherulitic and skeletal forms of the original clinopyroxene crystals, crystallization conditions even in the cumulate zone were certainly not near an equilibrium. Such crystallization conditions can have considerable and complex effects on the mineralogy (see Lofgren et al., 1974; Walker et al., 1976; Arndt et al., 1979).

\section{Discussion}

Komatiitic volcanics have been interpreted as having erupted in varied geotectonic environments. According to Viljoen \& Viljoen (1969a) they formed part of the primitive earth's crust, while others regard the komatiites and the tholeiites occurring with them as part of the ancient oceanic crust (Glikson, 1971; Ross \& Hopkins, 1975). More acidic metavolcanics of the calc-alkaline series have also been observed to occur in conjunction with the komatiites or overlying them, and consequently the ultramafic-mafic metavolcanics are taken to represent an oceanic crust below an island arc (Anhaeusser, 1973; Gelinas \& Brooks, 1974), or to form part of the volcanism of the island arc itself (Brooks \& Hart, 1972, 1974). Komatiites have also been regarded as the products of volcanism in back arc basins (Upadhyay \& Neale, 1979). There is clear evidence in Rhodesia, the Sahara and Canada of komatiites having erupted onto an older gneiss or granulite basement (Bickle et al., 1975; Chayka, 1976; Schwarz \& Fujiwara, 1977). It is proposed also that komatiites form part of the volcanism of continental margins (Bickle et al., 1975) or grabens (Nisbet et al., 1977; Naldrett \& Turner, 1977), but since Schau (1977) has also observed komatiites with quartzites, they must also have erupted in stable environments. The above opinions do not enable us to associate komatiites with any particular geotectonic surroundings.

The numerous pillow lavas occurring in the Kellojärvi Group without doubt constitute evidence of subaqueous magma eruptions and the fact that these pillows have no amygdules would indicate that the eruptions took place at a considerable depth, since vesicles are 
observed to decrease in amount and size with increasing water depth (Jones, 1969; Moore, 1970). It is admittedly possible that vesicles did form, but were destroyed during deformation and metamorphism. On the other hand, the preservation of skeletal plagioclase crystals in the metavolcanics of the Pahakangas Formation shows that only very little deformation has occurred.

The above-mentioned skeletal plagioclase crystals also offer further evidence in support of eruption at a great depth. Although not diagnostic for ocean-flloor basalts (cf. Downes, 1973; Mäkipää, 1978), such crystals do seem to be common in basalts of all ages which have erupted onto the ocean floor (Pearce \& Donaldson, 1974). They have been described in modern ocean-floor basalts (see Muir et al., 1966; Bryan, 1972; Hermes \& Schilling, 1976), as well as in Proterozoic metalavas (see Baragar, 1960; Pearce \& Donaldson, 1976) and younger, often spilitic, pillow lavas associated with ophiolites (Liou, 1974; Seguir \& Laurent, 1975) and other Alpine formations (see Vuagnat, 1959; Batley, 1956). The pillow lavas of the Pahakangas Formation also contain quartz-filled gas cavities of the kind that are abundant in ocean-floor basalts (Wells et al., 1978), and which according to Anhaeusser (ref. McCall, 1971; p. 431) are again indicative of a considerable depth of water.

Variolitic textures are frequently reported. in the marginal parts of pillows on the ocean floor (see Vallier, 1970; Bass et al., 1972; Melson \& Thompson, 1973; Yeats et al., 1973). Whether the varioles are simply phenomena associated with rapid crystallization, or whether they constitute a texture formed by immiscible silicate liquids, their generation takes place essentially under the influence of the chilling effect of sea water, for it is the resulting rapid cooling and consequent supercooling which is observed to yield spherulitic crystallization (Lofgren, 1974) and to promote liquid immiscibility (Carstens, 1963). Thus Furnes (1973) was led to suggest the use of variolitic texture as a criterion for deep-water conditions. The amounts of varioles and vesicles have indeed been observed to be inversely proportional (Wrucke et al., 1978).

There are thus many factors to support the interpretation that the lavas of the Kellojärvi Group were deposited in considerably deep water. Once the eruption of the acid volcanics of the Ontojärvi Group had taken place, however, it may be assumed that shallow-water conditions were attained, and in places even a sub-aerial environment, as indicated by the presence of quartzites with current bedding textures overlying the acid metavolcanics.

There are some descriptions in the literature of layered komatiitic sills and thick flows having ultramafic lower and mafic upper sections (see Arndt, 1977b; Nisbet et al., 1977; Francis \& Hynes, 1979). In such cases the parental magma is generally thought to have an $\mathrm{MgO}$ content in the range $14-20 \%$. In the Siivikkovaara area, and elsewhere in the Kuhmo greenstone belt, one finds relatively thin $(<20 \mathrm{~m})$ spinifex-textured lava flows which have both a parental magma composition and a liquid composition corresponding to pyroxenitic komatiite. Similar pyroxene spinifex-textured flows are known to exist in Rhodesia (Nisbet et al., 1977, Fig. 2), occasionally in Canada (Arndt et al., 1977, Fig. 14) and possibly also in South Africa (Williams \& Furnell, 1979, p. 334), although detailed descriptions of such instances are rare.

Francis \& Hynes (1979) demonstrate that komatiitic parent magmas with a $\mathrm{MgO}$ content of $14 \%$ must have given rise to tholeiitic differentiates rich in $\mathrm{Fe}$ and $\mathrm{Ti}$ via fractional crystallization in sills and thick flows in the Cape Smith fold belt of New Quebec, and 
also suggest that the penecontemporaneous tholeiitic metalavas constitute together with the komatiites a single magmatic suite controlled by low-pressure crystal fractionation. The differentiates of spinifex-textured lava flows in the Siivikkovaara area which have the lowest $\mathrm{MgO}$ content resemble chemically the tholeiites of the Pahakangas Formation. The latter are located in the extension to the komatiite field in the Jensen cation plot (Fig. 26), for example. The tholeiites of the Pahakangas Formation cannot be fractionation products of the same parental magma as the komatiites, however, as the Pahakangas Formation, being the oldest unit in the Kellojärvi Group, is situated below the Siivikkovaara Formation, but rather they obviously represent the products of an earlier upper mantle melting process. The pyroxenitic and basaltic komatiites of the Mäkinen Member, on the other hand, could be related to the peridotitic komatiites of the lower Siivikko Member through crystal fractionation. Major element trends in these units similar to those found in the spinifex-textured lava flows (see Fig. 26, for example) suggest that the varying degree of differentiation could be caused by olivine fractionation and possible minor clinopyroxene fractionation. An immobile trace element study (particularly using REE) would be needed to verify this model. The compositional gap between $15 \%$ and $18 \% \mathrm{MgO}$ within the metalavas of the Siivikkovaara Formation, however, supports the view that the pyroxenitic and basaltic komatiites of the Mäkinen Member must be the results of a separate, lower degree upper mantle melting episode.

Komatiitic rocks have proved very promising for nickel prospecting (see Naldrett \& Cabri, 1976), and according to Naldrett \& Arndt (1976) those komatiites which are most likely to contain nickel and copper deposits are dunitic rocks having an $\mathrm{MgO}$ content of
$40 \%$ or more (in volatile-free analyses). Despite the generally relatively low magnesium content of the komatiites of the Siivikkovaara Formation, two nickel and copper mineralizations are known to exist, the small, and at present uneconomic, Arola deposit about $22 \mathrm{~km}$ north of Siivikkovaara, and a nickel-copper mineralization discovered quite recently in the Siivikkovaara area itself. The former site is closely associated with highly deformed and altered variolitic pillow lavas which seem to belong to the Mäkinen Member, while the latter is situated at the contact between the Siivikko and Mäkinen Members. The host rock of this latter mineralization, which is still under active investigation, is an ultramafic actinolite - chlorite (- talc - carbonate) -rock together with gabbroic rock, the latter type resembling chemically and mineralogically the spinifextextured rock of the Siivikkovaara area. The $\mathrm{Ni} / \mathrm{Cu}$ ratio calculated from samples obtained from the investigation trench, an average of 1.5: 1, is not typical of nickel-copper deposits associated with komatiites (cf. Gemuts \& Theron, 1975).

Acknowledgements - This work was carried out at the University of Oulu as a part of the investigations of the Kuhmo Research Project financed by the Ministry of Trade and Industry. I wish to express my warmest thanks to my colleagues Mr. Kalle Taipale, M.Sc. and Mr. Ilkka Tuokko, B.Sc. for many useful discussions. I am deeply grateful to my teacher and the scientific leader of the project, Professor Tauno Pirainen, for his continuous interest in my study and for the encouragement he has given me. I am grateful to Mr. Sylvain Blais, M.A., for providing an analysis from the Pahakangas Formation. I am indepted to Professors Heikki Papunen and Atso Vorma and Dr. Kauko Meriläinen for critically reading the manuscript and for providing valuable suggestions. I would also like to thank Mr. Malcolm Hicks, M. A. and Dr. Sheila Hicks for translating the manuscript into English. This investigation was supported by the IGCP Project no. 161 and this support is gratefully acknowledged. 


\section{References}

Abbey, S., Lee, N. J. and Bouvier, J. L. (1974) Analysis of rocks and minerals using an atomic absorption spectrophotometer. Part 5. An improved lithium-fluoborate scheme for fourteen elements. Geol. Survey Canada, Paper 74-19, $26 \mathrm{p}$.

Anhaeusser, C. R. (1973) The evolution of the early Precambrian crust of Southern Africa. Phil. Trans. R. Soc. London, Ser A. 273, 359-388.

Arndt, N. T. (1976) Melting relations of ultramafic lavas (komatiites) at one atmosphere and high pressure. Carnegie Inst. Wash. Yearb. 75, 555562.

Arndt, N. T. (1977a) Mineralogical and chemical variation in two thick, layered komatiitic lava flows. Carnegie Inst. Wash. Yearb. 76, 494502 .

- (1977b) Thick, layered peridotite-gabbro Iava flows in Munro Township, Ontario. Can. J. Earth Sci. 14, 2620-2637.

- (1977c) Partitoning of nickel between olivine and ultrabasic and basic liquids. Carnegie Inst. Wash. Yearb. 76, 553-557.

- , Francis, D. and Hynes, A. J. (1979) The field characteristics and petrology of Archean and Proterozoic komatiites. Can. Mineral. 17, 147163.

- , Naldrett, A. J. and Pyke, D. R. (1977) Komatiitic and iron-rich tholeiitic lavas of Munro Township, Northeast Ontario. J. Petrol. 18, $319-369$.

Baragar, W. R. A., Plant, A. G., Pringle, G. J. and Schaw, M. (1977) Petrology and alteration of selected units of Mid-Atlantic Ridge basalts sampled from sites 332 and 335, DSDP. Can. J. Earth Sci. 14, 837-874.

Barnes, R. G., Lewis, J. D. and Gee, R. D. (1974) Archaean ultramafic lavas from Mount Clifford. Annu. Rep. Geol. Surv. West Aust. 1973, $59-70$.

Bass, M. N., Reid, A. M. and Takeda, H. (1973) Disordered albite and oligoclase from veins in metabasalt. In: R. Shagam et al. (Eds.), Studies in Earth and Space Sciences (Hess volume). Geol. Soc. Am. Mem. 132, 535-552.

Battey, M. H. (1956) The petrogenesis of a spilitic rock series from New Zealand. Geol. Mag. 93, $89-110$.

Bickle, M. J., Martin, A. and Nisbet, E. G. (1975) Basaltic and peridotitic komatiites and stromatolites above a basal unconformity in the Belingwe greenstone belt, Rhodesia. Earth Planet.
Sci. Lett. 27, 155-162.

Blais, S., Auvray, B., Capdevila, R., Jahn, B. M. and Hameurt, J. (1978) The Archaean greenstone belts of Karelia (Eastern Finland) and their komatiitic and tholeiitic series. In: B. F. Windley \& S. M. Naqvi (Eds.), Archaean Geochemistry, Elsevier Co., 87-107.

- et al. (in prep.) Spinifex-textured peridotitic komatiites from the Tipasjärvi Archean greenstone belt, Eastern Finland.

Boyd, F. R. and Smith, D. (1971) Compositional zoning in pyroxenes from Lunar Rock 12021, Oceanus Procellarum. J. Petrol. 12, 439-464.

Brooks, D. and Hart, S. R. (1972) An extrusive basaltic komatiite from a Canadian metavolcanic belt. Can. J. Earth Sci. 9, 1250-1253.

- and Hart, S. R. (1974) On the significance of komatiite. Geology 2, 107-110.

Bryan, W. B. (1972) Morphology of quench crystals in submarine basalts. J. Geophys. Res. 77, $5812-5819$.

Carstens, H. (1963) On the variolitic structure. Norges Geol. Unders. 223, 26-42.

Chayka, V. M. (1976) Proterozoic komatiite of the Central Sahara. Doklady Akad. Nauk. SSSR 231, 155-157.

Condie, K. C. and Harrison, N. M. (1976) Geochemistry of the Archean Bulawayan Group, Midlands greenstone belt, Rhodesia. Precambrian Res. 3, 253-271.

Dessai, A. G. and Deshpande, G. G. (1979) Komatiites from Sanguem area, Goa, India. Neues Jahrb. Miner. Abh. 135, 209-220.

Dimroth, E. and Lichtblau, A. P. (1978) Oxygen in the Archean ocean: comparison of ferric oxide crusts on Archean and Cenozoic pillow basalts. Neues Jahrb. Miner. Abh. 133, 1-22.

Donaldson, C. H. (1974) Olivine crystal types in harrisitic rocks of the Rhum pluton and in Archean spinifex rocks. Geol. Soc. Am. Bull. 85, 1721-1726.

- (1976) An experimental investigation of olivine morphology. Contrib. Min. Petrol. 57, 187-214.

Downes, M. J. (1973) Some experimental studies on the 1971 lavas from Etna. Phil. Trans. R. Soc. London, Ser. A, 274, 55-62.

Dowty, E., Keil, K. and Pring, M. (1974) Lunar pyroxenephyric basalts: crystallization under supercooled conditions. J. Petrol. 15, 419-453.

Duke, J. M. and Naldrett, A. J. (1978) A numerical model of the fractionation of olivine and molten sulfide from komatiite magma. Earth Planet. Sci. Lett. 39, 255-266. 
Ferguson, J. and Currie, K. L. (1972) Silicate liquid immiscibility in the ancient sbasalts» of the Barberton Mountain Land, Transvaal. Nat. Phys. Sci. 235, 86-89.

Fleet, M. E. and MacRae, N. D. (1975) A spinifex rock from Munro Township, Ontario. Can. J. Earth Sci. 12, 928-939.

Francis, D. M. and Hynes, A. J. (1979) Komatiitederived tholeiites in the Proterozoic of New Quebec. Earth Planet. Sci. Lett. 44, 473--481.

Furnes, H. (1973) Variolitic structure in Ordovician pillow lava and its possible significance as an environmental indicator. Geology 1, 27-30.

Gaál, G., Mikkola, A. and Söderholm, B. (1978) Evolution of the Archean crust in Finland. Precambrian Res. 6, 199-215.

Gelinas, L. and Brooks, C. (1974) Archean quench texture tholeiites. Can. J. Earth Sci. 11, 324340.

- , Lajoie, J., Brooks, C., Cloutier, M. and Valiquette, G. (1975) Ultramafic tuff: another Archean-only phenomenon? Geol. Soc. Am. Abs. with Programs 7, 761-762.

- , Brooks, C. and Trzcienski, W. E. J. (1976) Archean variolites - quenched immiscible liquids. Can. J. Earth Sci. 13, 210-230.

- , Lajoie, J. and Brooks, C. (1977) The origin and significance of Archean volcanoclastics from Spinifex Ridge, La Motte Township, Quebec. Geol. Assoc. Can. Spec. Pap. 16, 297-309.

Geological Survey of Finland. Annual Reports on the activities for the year 1975. Geol. Surv. Finland, Otaniemi.

Gill, R. C. O. (1979) Comparative petrogenesis of Archaean and modern low- $\mathrm{K}$ tholeiites. A critical review of some geochemical aspects. In: L. H. Ahrens and G. Protas (Eds.) Origin and Distribution of the Elements, Pergamon Press, $431-447$.

Glikson, A. Y. (1971) Primitive Archean element distribution patterns: chemical evidence and geotectonic significance. Earth Planet. Sci. Lett. $12,309-320$.

Hallberg, J. A. and Williams, D. A. C. (1972) Archean mafic and ultramafic rock associations in the Eastern Goldfields region, Western Austalia. Earth Planet. Sci. Lett. 15, 191-200.

- , Carter, D. N. and West, K. N. (1976) Archean volcanism and sedimentation near Meekatharra, Western Australia. Precambrian Res. 3, 577-595.

Hermes, O. D. and Schilling, J.-G. (1976) Olivine from Reykjanes Ridge and Iceland tholeiites, and its significance to the two-mantle source model. Earth Planet. Sci. Lett. 28, 345-355.

Hyppönen, V. (1976) Geological Map of Finland. Pre-Quarternary rocks, Sheet 4411, Ontojoki. Geol. Surv. Finland.

Irvine, T. N. and Baragar, W. R. A. (1971) A guide to the chemical classification of the common volcanic rocks. Can. J. Earth Sci. 8, 523-548.

Isomaa, J. (1978) Keski-Lapin liuskemuodostuma Petkulan alueella Sodankylän pohjoispuolella. Unpub. M. S. thesis, Univ. Oulu, Dept. of Geology, $92 \mathrm{pp}$.

Jensen, L. S. (1976) A new cation plot for classifying subalkalic volcanic rocks. Ont. Dep. Min. Misc. Pap. 66, 22 pp.

Jolly, W. T. (1975) Subdivision of the Archean lavas of the Abitibi area, Canada, from Fe-Mg$\mathrm{Ni}-\mathrm{Cr}$ relations. Earth Planet. Sci. Lett. 27, $200-210$.

Karvinen, W. O. (1978) The Porcupine camp - A model for gold exploration in the Archean. Can. Min. J. 99 (9), 48-53.

Kretschmar, U. and Kretschmar, D. (1975): Geology and ultramafic flows of the Malartic Group, N.W. Quebec. Geol. Soc. Am. Abstr. with Programs 7, 801-802.

Lajoie, J. and Gelinas, L. (1978) Emplacement of Archean peridotitic komatiites in La Motte Township, Quebec. Can. J. Earth Sci. 15, 672677.

Lehto, T. and Niiniskorpi, V. (1977) Pohjois- ja Itä-Suomen rautamuodostumat. Summary: The iron formations of northern and eastern Finland. Geol. Surv. Finland, Rep. Invest. 22, $49 \mathrm{pp}$.

Liou, J. G. (1974) Mineralogy and chemistry of glassy basalts, Coastal Range ophiolites, Taiwan. Geol. Soc. Am. Bull. 85, 1-10.

Lofgren, G. E. (1971) Spherulitic textures in glassy and crystalline rocks. J. Geophys. Res. 76, $5635-5648$.

- (1974) An experimental study of plagioclase crystal morphology: isothermal crystallization. Am. J. Sci. 274, 243-273.

- , Donaldson, C. H., Williams, R. J., Mullins, O. $J r$. and Usselman, T. M. (1974) Experimentally reproduced textures and mineral chemistry of Apollo 15 quartz normative basalts. Proc. Lunar Sci. Conf. 5th, 549-568.

-, Donaldson, C. H. and Usselman, T. M. (1975) Geology, petrology and crystallization of Apollo 15 quartz-normative basalts. Proc. Lunar Sci. Conf. 6th, 79-99. 
Luukkonen, E. (1978) Moisiovaaran alueen arkeinen kallioperä Kuhmo-Suomussalmen liuskejaksolla. Unpub. M.S. thesis, Univ. Oulu, Dept. of Geology, $109 \mathrm{pp}$.

MacDonald, G. A. (1976) Forms and structures of extrusive basaltic rocks. In: $\mathrm{H}$. H. Hess and A. Poldervaart (Eds.), Basalts. Volume 1. John Wiley and Sons, $1-61$.

Matisto, A. (1954) General Geological Map of Finland. Pre-Quarternary rocks, Sheet D5, Suomussalmi. Geol. Surv. Finland.

McCall, F. J. H. (1971) Some ultrabasic and basic igneous rock occurrences in the Archaean of Western Australia. Geol. Soc. Aust. Spec. Publ. $3,429-442$.

McCall, G. J. H. (1973) Geochemical characteristics of some Archaean greenstone suites of the Yilgarn structural province, Australia. Chem. Geol. 11, $243-270$.

- and Leishman, J. (1971) Clues to the origin of Archaean ophiolitic peridotites and the nature of serpentinisation. Spec. Publ. Geol. Soc. Aust. 3, 281-299.

McGregor, V. R. and Mason, B. (1977) Petrogenesis and geochemistry of metabasaltic and metasedimentary enclaves in the Amitsoq gneisses, West Greenland. Am. Mineral. 62, 887-904.

McIver, J. R. (1975) Aspects of some high magnesia eruptives in southern Africa. Contr. Mineral. Petrol. 51, 99-118.

Melson, W. G. and Thompson, G. (1973) Glassy abyssal basalts, Atlantic sea floor near St. Paul rocks: petrography and composition of secondary clay minerals. Geol. Soc. Am. Bull. 84, $703-716$.

Meriläinen, $K$. (1976) The granulite complex and adjacent rocks in Lapland, northern Finland. Geol. Surv. Finland, Bull. 281, 129 pp.

Mikkola, E. (1941) Suomen geologinen yleiskartta - The general geological map of Finland, sheets B7, C7, D7, Muonio-Sodankylä-Tuntsajoki. Kivilajikartan selitys - Explanation to the map of rocks, Geol. Surv. Finland, $286 \mathrm{p}$.

Moore, J. G. (1970) Water content of basalt erupted on the ocean floor. Contr. Mineral. Petrol. 28, $272-279$.

Muir, I. D., Tilley, D. E. and Scoon, J. H. (1966) Basalts from the northern part of the MidAtlantic Ridge. J. Petrol. 7, 193-201.

Mutanen, T. (1976) Komatiites and komatiite provinces in Finland. Geologi 28, 40-56.

Mäkipää, H. (1978) Petrological relations in some
Icelandic basaltic hyaloclastites. Bull. Geol. Soc. Finland 50, 81-112.

Naldrett, A. J. and Arndt, N. T. (1976) Volcanogenic nickel deposits with some guides for exploration. Soc. Min. Eng. Trans. 260, 13-15.

- and Cabri, L. J. (1976) Ultramafic and related rocks: Their classification and genesis with special reference to the concentration of nickel sulfides and platinum-group elements. Econ. Geol. 71, 1131-1158.

- and Turner, A. R. (1977) The geology and petrogenesis of a greenstone belt and related nickel sulfide mineralization at Yakabindie, Western Australia. Precambrian Res. 5, 43-103.

Nesbitt, R. W. (1971) Skeletal crystal forms in the ultramafic rocks of the Yilgarn Block, Western Australia: Evidence for an Archaean ultramafic liquid. Geol. Soc. Aust. Spec. Publ. 3, 331-350.

- and Sun, S. S. (1976) Geochemistry of Archaean spinifex-textured peridotites and magnesian and low-magnesian tholeiites. Earth Planet. Sci. Lett. 31, 433-453.

Niiniskorpi, V. (1975) Itä-Suomen horisonttaalisidonnaiset rautamuodostumat. Lapin rautamalmien horisonttisidonnaisuusprojekti. PohjoisSuomen malmigeologinen toimikunta. Report PSMT/P10/76/3. Unpubl. Rep. Arch. Geol. Surv. Finland.

Nisbet, E. G., Bickle, M. J. and Martin, A. (1977) The mafic and ultramafic lavas of the Belingwe Greenstone Belt, Rhodesia. J. Petrol. 18, $521-566$.

Paakkola, J. (1971) The volcanic complex and associated manganiferous iron formation of the Porkonen-Pahtavaara area in Finnish Lapland. Bull. Comm. géol. Finlande 247, 83 pp.

Papunen, H. (1960) Havaintoja Siivikkovaaran alueen kallioperästä Kuhmon pitäjän Vieksin kylästä. Unpubl. M.S. thesis, Univ. Helsinki, Dept. of Geology, $56 \mathrm{pp}$.

- , Idman, H., Ilvonen, E., Neuvonen, K. J., Pihlaja, P. and Talvitie, J. (1977) Lapin ultramafiiteista. Geol. Surv. Finland, Rep. Invest. 23, $87 \mathrm{pp}$.

Pearce, T. H. (1968) A contribution to the theory of variation diagrams. Contr. Mineral. Petrol. $19,142-157$.

- and Birkett, T. C. (1974) Archean metavolcanic rocks from Thackeray Township, Ontario. Can. Mineral. 12, 509-519.

- and Donaldson, J. A. (1974) Proterozoic quenchtexture basalts from the Labrador Geosyncline. Can. J. Earth Sci. 11, 1611-1615. 
Philpotts, A. R. (1977) Archean variolites quenched immiscible liquids: Discussion. Can. J. Earth. Sci. 14, 139-144.

Pyke, D. R., Naldrett, A. J. and Eckstrand, O. R. (1973) Archaean ultramafic flows in Munro Township, Ontario. Bull. Geol. Soc. Am. 84, 955-978.

Rogers, P. S. (1970) The initiation of crystal growth in glasses. Mineral. Mag. 37, 741-758.

Ross, J. R. and Hopkins, G. M. F. (1975) Kambalda nickel sulfide deposits. In: C. L. Knight (Ed.), Economic Geology of Australia and Papua New Guinea -1. Metals. Australas. Inst. Min. Metal., Monogr., 5, 185-195.

Schau, M. (1977) »Komatiites» and quartzites in the Archean Prince Albert Group. Geol. Assoc. Can. Spec. Paper 16, 341-354.

Schwarz, E. J. and Fujiwara, Y. (1977) Komatiitic basalts from the Proterozoic Cape Smith Range in northern Quebec, Canada. Geol. Assoc. Can. Spec. Paper 16, 193-201.

Seguin, M. K. and Laurent, R. (1975) Petrological features and magnetic properties of pillow lavas from the Thetford Mines Ophiolite, Quebec. Can. J. Earth Sci. 12, 1406-1420.

Seyfried, W. E. Jr., Mottil, M. J. and Bischoff, J. L. (1978) Seawater/basalt ratio effects on the chemistry and mineralogy of spilites from the ocean floor. Nature 275, 211-213.

- and Bischoff, J. L. (1979) Low temperature basalt alteration by seawater: an experimental study at $70^{\circ} \mathrm{C}$ and $150^{\circ} \mathrm{C}$. Geochim. Cosmochim. Acta 43, 1937-1948.

Sun, S.-S. and Nesbitt, R. W. (1978) Petrogenesis of Archaean ultrabasic and basic volcanics: evidence from rare earth elements. Contr. Mineral. Petrol. 65, 301-325.

- Nesbitt, R. W. and Sharaskin, A. Ya. (1979) Geochemical characteristics of mid-ocean ridge basalts. Earth Planet. Sci. Lett. 44, 119-138.

Suslova, S. N. (1976) Komatiite in lower Precambrian metavolcanic units of the Kola Peninsula. Dokl. Akad. Nauk SSSR 228, 697-700.

Taipale, K. (1979) Arkeisen vulkanismin kehitys Tipasjärven alueella. Kuhmo and Kittilä Research Projects, University of Oulu. Report 14, $46 \mathrm{pp}$.

Tuokko, I. (1979) Kuhmon-Suomussalmen liuskejakson rautamuodostumat ja niiden stratigrafinen sijainti. Kuhmo and Kittilä Research Projects, University of Oulu. Report 16, $82 \mathrm{pp}$.

Upadhyay, H. D. (1978) Phanerozoic peridotitic and pyroxenitic komatiites from Newfoundland. Science 203, 1192-1195.
- and Neale, E. R. W. (1979) On the tectonic regimes of ophiolite genesis. Earth Planet. Sci. Lett. $43,93-102$.

Vallier, T. L. (1970) Volcanism. In: D. A. McManus et al. (Eds.) Initial Reports of the Deep Sea Drilling Project, vol. V. Wash. D. C. Gov. Print. Off., 531-534.

Viljoen, M. J. and Viljoen, R. P. (1969a) The geology and geochemistry of the Lower Ultramafic Unit of the Onverwacht Group and a proposed new class of igneous rocks. Geol. Soc. South Afr. Spec. Publ. 2, 55-86.

Viljoen, R. P. and Viljoen, M. J. (1969b) The geological and geochemical significance of the upper formations of the Onverwacht Group. Geol. Soc. South Afr. Spec. Publ. 2, 113-152.

Vuagnat, M. (1959) Les basaltes en coussins d'Aci Castello et du val di Noto. Estratto Rendic. Soc. Mineral. Italiana 15, 311-323.

Walker, D., Kirkpatrick, R. J., Longhi, J. and Hays, J. F. (1976) Crystallization history of lunar picritic basalt sample 12002: Phase-equilibria and cooling-rate studies. Geol. Soc. Am. Bull. 87, 646-656.

Weigand, P. W. and Hollister, L. S. (1973) Basaltic vitrophyre 15597: an undifferentiated melt sample. Earth Planet. Sci. Lett. 19, 61-74.

Wells, G., Bryan, W. B. and Pearce, T. H. (1979) Comparative morphology of ancient and modern pillow lavas. J. Geology 87, 427-440.

Whitword, D. and Arndt, N. T. (1977) Rare earth elements in a thick, layered komatiite lava flow. Carnegie Inst. Wash. Yearb. 76, 594-598.

Wilkman, W. W. (1924) Suomen geologinen yleiskartta, lehti D4, Nurmes - General Geological Map of Finland. Sheet D4, Nurmes. Geol. Surv. Finland.

Williams, D. A. C. and Furnell, R. G. (1979) Reassessment of part of the Barberton type area, South Africa. Precambrian Res. 9, 325-348.

Wrucke, C. T., Churkin, M. Jr. and Heropoulos, C. (1978) Deep-sea origin of Ordovician pillow basalt and associated sedimentary rocks, northern Nevada. Geol. Soc. Am. Bull. 89, 1272-1280.

Wyllie, P. J. (1963) Effects of the changes in slope occuring on liquidus and solidus paths in the system diopside-anorthite-albite. Mineral. Soc. Amer., Spec. Paper 1, 204-212.

Yeats, R. S., Forbes, W. C., Scheidegger, K. F., Ross Hearh, G. and Andel, Tj. H. van (1973) Core from a Cretaceous basalt, Central Equatorial Pacific, Leg. 16, Deep Sea Drilling Project. Geol. Soc. Am. Bull. 84, 871-882.

Manuscript received, February 20, 1980 